Review

\title{
Sustainable, Smart, and Sensing Technologies for Cyber-Physical Manufacturing Systems: A Systematic Literature Review
}

\author{
Mihai Andronie ${ }^{1}\left(\mathbb{D}\right.$, George Lăzăroiu ${ }^{1, *}$, Roxana Ștefănescu ${ }^{2}\left(\mathbb{D}\right.$, Cristian Uță $^{1}$ and Irina Dijmărescu ${ }^{3}$ \\ 1 Department of Economic Sciences, Spiru Haret University, 030045 Bucharest, Romania; \\ mihai_a380@spiruharet.ro (M.A.); cristi.uta@gmail.com (C.U.) \\ 2 Department of Juridical Sciences and Economic Sciences, Spiru Haret University, 500152 Brașov, Romania; \\ roxanastefanescu72@yahoo.com \\ 3 Department of Pediatrics, Grigore Alexandrescu Children's Emergency Hospital, 011743 Bucharest, Romania; \\ irinaandronie@yahoo.com \\ * Correspondence: phd_lazaroiu@yahoo.com
}

check for

updates

Citation: Andronie, M.; Lăzăroiu, G.; Ștefănescu, R.; Uță, C.; Dijmărescu, I. Sustainable, Smart, and Sensing Technologies for Cyber-Physical Manufacturing Systems: A Systematic Literature Review. Sustainability 2021, 13, 5495. https:// doi.org/10.3390/su13105495

Academic Editors: Elvira Nica, Miloš Poliak and Vladimír Konečný

Received: 24 March 2021

Accepted: 7 May 2021

Published: 14 May 2021

Publisher's Note: MDPI stays neutral with regard to jurisdictional claims in published maps and institutional affiliations.

Copyright: (c) 2021 by the authors. Licensee MDPI, Basel, Switzerland. This article is an open access article distributed under the terms and conditions of the Creative Commons Attribution (CC BY) license (https:// creativecommons.org/licenses/by/ $4.0 /)$.

\begin{abstract}
With growing evidence of the operational performance of cyber-physical manufacturing systems, there is a pivotal need for comprehending sustainable, smart, and sensing technologies underpinning data-driven decision-making processes. In this research, previous findings were cumulated showing that cyber-physical production networks operate automatically and smoothly with artificial intelligence-based decision-making algorithms in a sustainable manner and contribute to the literature by indicating that sustainable Internet of Things-based manufacturing systems function in an automated, robust, and flexible manner. Throughout October 2020 and April 2021, a quantitative literature review of the Web of Science, Scopus, and ProQuest databases was performed, with search terms including "Internet of Things-based real-time production logistics", "sustainable smart manufacturing", "cyber-physical production system", "industrial big data", "sustainable organizational performance", "cyber-physical smart manufacturing system", and "sustainable Internet of Thingsbased manufacturing system". As research published between 2018 and 2021 was inspected, and only 426 articles satisfied the eligibility criteria. By taking out controversial or ambiguous findings (insufficient/irrelevant data), outcomes unsubstantiated by replication, too general material, or studies with nearly identical titles, we selected 174 mainly empirical sources. Further developments should entail how cyber-physical production networks and Internet of Things-based real-time production logistics, by use of cognitive decision-making algorithms, enable the advancement of data-driven sustainable smart manufacturing.
\end{abstract}

Keywords: sustainable smart manufacturing; artificial intelligence-based decision-making algorithm; big data analytics; cyber-physical production system; digital twin; sensing technology

\section{Introduction}

There is a growing body of literature concerning the sustainable operational performance [1-4] of cyber-physical manufacturing systems in terms of Internet of Things-based real-time production logistics. Internal and external sustainability practices throughout supply chains catalyze organizational performance. The enhanced financial operations from sustainability management [5-8] are traceable to superior product image, sales, and increased market prospects, and consequently administering the sustainability initiatives in companies is decisive. Supply chains represent a synergistic and robust component of organizational competitive advantage. With the amplifying sensitivity to environmental protection and fluid business settings, companies can decide upon taking more operational strategies to carry out the likely facilities supplied by sustainable business practices. Heterogeneous sustainability management routines [9-12] are related to reduced carbon energy utilization and actions to prevent the intensification of climate change. Sustainable 
supply chain management constitutes a necessary condition for advancing sound business models [13-15] compatible with extended objectives. The striving towards sustainable supply chain management develops out of the demands of the present-time world, while cost-effectiveness and handling of natural resources are instrumental in waste decrease, breakthroughs, bringing about profits, and articulating a unique perceived benefit. Durable investments are essential for future-oriented companies and sustainable development.

The objective of this systematic review is to analyze the lately published literature on sustainable, smart, and sensing technologies for cyber-physical manufacturing systems and synthesize the insights it articulates on sustainable smart manufacturing. By inspecting the most recent (2018-2021) and relevant (Web of Science, Scopus, and ProQuest) sources, this research has endeavored to prove that sustainable smart manufacturing, through data-driven Internet of Things systems, assimilates complete input of product lifecycle operations. The actuality and novelty of our research are configured by addressing sustainable smart manufacturing as cyber-physical production systems, which is a hot emerging topic. The research problem developed throughout the article is whether the cyber-manufacturing system harnesses innovative advancements in Internet of Thingsbased real-time production logistics, cognitive automation, and industrial big data analytics. The manufacturing cyber-physical system possesses progressively automated linkages and networking, leading to big data-driven innovation in sustainable Industry 4.0. Industry 4.0 generates cutting-edge developments in sustainable operations [16] and may attain uniform production and consumption practices through cognitive decision-making algorithms across artificial intelligence data-driven Internet of Things systems.

In this research, previous findings were cumulated, showing that cyber-physical production networks operate automatically and smoothly [5,17-19] with artificial intelligencebased decision-making algorithms and Internet of Things-based real-time production logistics. Our main objective is to indicate that, throughout cyber-manufacturing networks, production parts and smart connected sensors interconnect automatically [20-22], resulting in sustainable organizational performance. This systematic review contribute to the literature on sustainable, smart, and sensing technologies for cyber-physical manufacturing systems by clarifying that Internet of Things-based real-time production logistics functions in an automated, robust, and flexible manner. This research attempts to elucidate whether cutting-edge sensing and streamlining infrastructure management is prevalent in sustainable smart manufacturing. Our contribution is by articulating connected research findings proving that integrated Industry 4.0-circular economy reinforces sustainable operations management [23] by constantly upgrading the production and consumption practices through big data analytics-enabled cognitive decision-making algorithms. The objectives of sustainable Industry 4.0 for deploying big data technologies, deep learning-assisted smart process planning, and advanced analytics [24] are to carry out manufacturing efficiency by use of technological breakthroughs. The advancement of sustainable industrial value creation, artificial intelligence-based decision-making algorithms, Internet of Things-based real-time production logistics, and deep learning-assisted smart process planning as cuttingedge technologies of Industry 4.0 have furthered the shift towards cyber-manufacturing networks where production parts and smart sensors interconnect automatically.

\section{Methodology}

A systematic review of lately published literature was conducted on sustainable, smart, and sensing technologies for cyber-physical manufacturing systems by using Preferred Reporting Items for Systematic Reviews and Meta-analysis (PRISMA) guidelines. The inclusion criteria were (i) publications indexed in the Web of Science, Scopus, and ProQuest databases; (ii) publication date between 2018 and 2021; (iii) written in English; (iv) being an original empirical research or review article; and (v) certain search terms covered; (i) conference proceedings, (ii) books, and (iii) editorial materials were removed from the research. The Systematic Review Data Repository (SRDR) was employed, a software program for the collection, processing, and inspection of data for our systematic review. 
The quality of the specified scholarly sources was evaluated by using the Mixed Method Appraisal Tool. Extracting and analyzing publicly accessible files (academic articles) as evidence, no institutional ethics approval was required before starting our research (Figure 1).

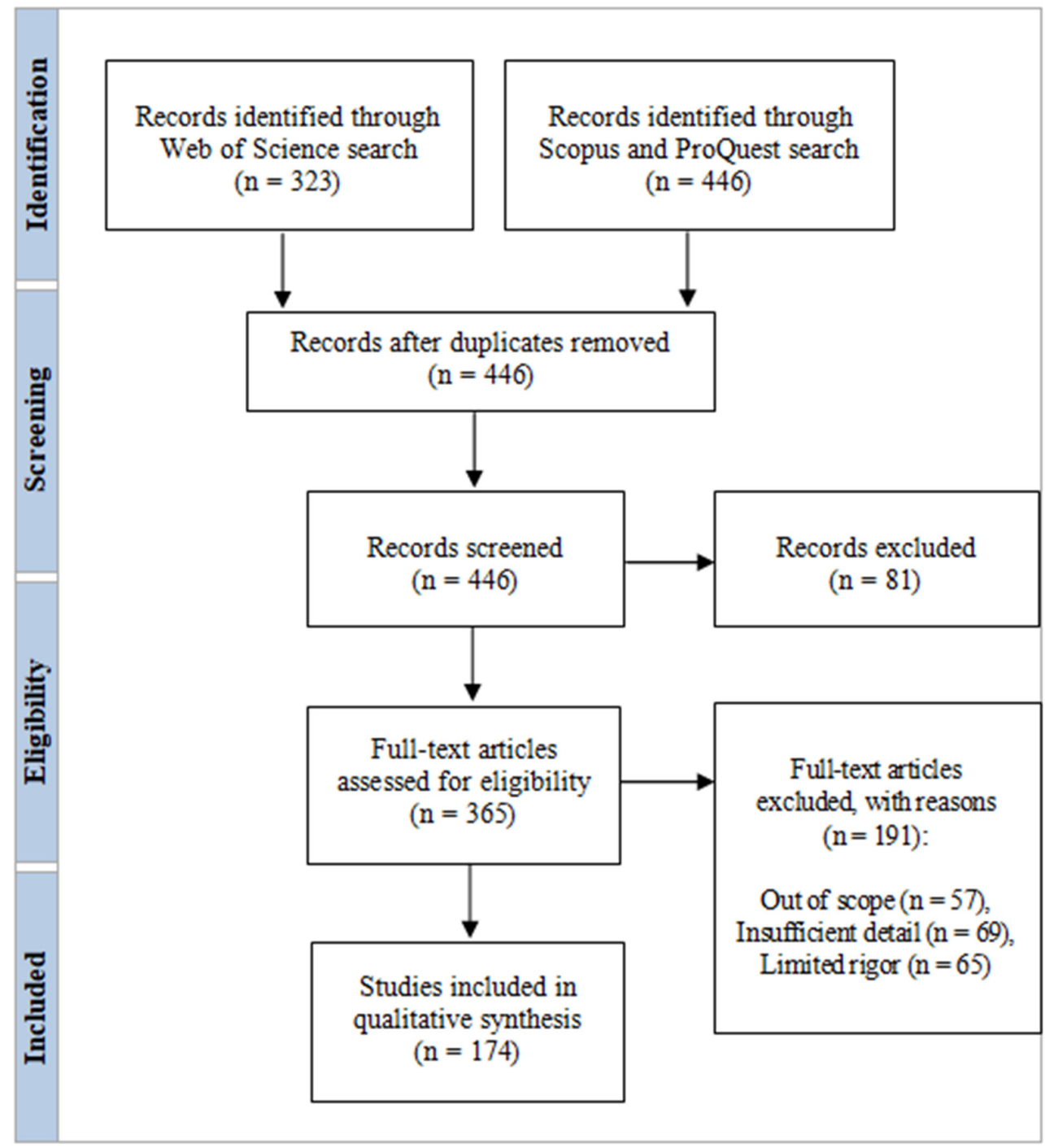

Figure 1. PRISMA flow diagram describing the search results and screening.

Throughout October 2020 and April 2021, a quantitative literature review of the Web of Science, Scopus, and ProQuest databases was performed, with search terms including "Internet of Things-based real-time production logistics", "sustainable smart manufacturing", "cyber-physical production system", "industrial big data", "sustainable organizational performance", "cyber-physical smart manufacturing system", and "sustainable Internet of Things-based manufacturing system". The search terms were identified as being the most used words or phrases throughout the investigated literature. As the inspected research was published between 2018 and 2021, only 426 articles satisfied the eligibility criteria. By taking out controversial or ambiguous findings (insufficient/irrelevant data), outcomes unsubstantiated by replication, too general material, or having nearly identical titles, we selected 174 mainly empirical sources (Tables 1 and 2). 
Table 1. Topics and types of paper identified and selected.

\begin{tabular}{ccc}
\hline Topic & Identified & Selected \\
\hline Internet of Things-based real-time production logistics & 38 & 20 \\
Sustainable smart manufacturing & 97 & 40 \\
Cyber-physical production system & 88 & 34 \\
Industrial big data & 80 & 27 \\
Sustainable organizational performance & 62 & 23 \\
Cyber-physical smart manufacturing system & 31 & 16 \\
Sustainable Internet of Things-based manufacturing system & 30 & 14 \\
\hline Type of paper & & \\
\hline Original research & 312 & 167 \\
Review & 33 & 7 \\
Conference proceedings & 44 & 0 \\
Book & 16 & 0 \\
Editorial & 21 & 0 \\
\hline
\end{tabular}

Source: Processed by the authors. Some topics overlap.

Table 2. General summary of evidence concerning focus topics and descriptive results (research outcomes).

By deploying groundbreaking sensors, input modeling, computing, and big data analytics technologies, cyber-physical production systems can become smart and sustainable.

Implementation of sustainable smart manufacturing may assist in attaining a data- and service-driven product lifecycle management.

Sustainable smart manufacturing enhances the automated level of design, fabrication, servicing, and recovery by use of evaluation and distribution of lifecycle data across the entire supply chain.

Integrated Industry 4.0-circular economy reinforces sustainable operations management by constantly upgrading the production and consumption practices. operations, making the supply chain more fluid and coherent.
Industry 4.0 generates cutting-edge developments in sustainable

Bennett et al., 2020; Bratu, 2018; Chessell and Neguriță, 2020;

Coatney, 2018; Ghobakhloo, 2020; Hardingham et al., 2018;

Kovacova et al., 2019; Leng et al., 2019; Lyakina et al., 2019;

Morgan et al., 2021; Popescu et al., 2020; Ren et al., 2019;

Rowthorn, 2019; Sawyer, 2020

Androniceanu et al., 2020; Brown et al., 2020; Gutschow, 2019; Haseeb et al., 2019; Hughes, 2020; Ionescu, 2020; Kral et al., 2019; Mitchell, 2021; Oláh et al., 2020; Olsen, 2019; Riegler, 2019; Riley et al., 2021; Sion, 2018

Bailey, 2021; Birkel and Müller, 2020; Bourke et al., 2019; Cunningham, 2021; Gutberlet, 2019; Kovacova et al., 2019; Lyakina et al., 2019; McGinnis, 2019; Mircică, 2020; Moore, 2020; Nica, 2018; Popescu Ljungholm, 2019

Bekken, 2019; Ionescu, 2019; Keane, 2020; Meilă, 2018; Mircică, 2019; Nica et al., 2018; Nica et al., 2019; Nica et al., 2021; Smith and Stirling, 2018; Song and Moon, 2019; Vochozka et al., 2018; Watkins, 2021; Yadav et al., 2020

Adams, 2020; Ashander et al., 2019; Dabija et al., 2018; Davis, 2020; Durana et al., 2021; Durst, 2019; Keane et al., 2020; Popescu et al., 2020; Rogers, 2021; Russell, 2020; Schinckus, 2018; Tötzer et al., 2019; Williams et al., 2020

The sustainable and groundbreaking product design and deep learning-assisted smart process planning can be attained by use of adequate management of the input collected throughout sequential product design and business process optimization in sustainable smart manufacturing through cognitive decision-making algorithms across artificial intelligence data-driven Internet of Things systems.

Through big data analytics-enabled cognitive decision-making algorithms, the performance of the entire lifecycle management operations and service supplying developed on sustainable smart manufacturing can be monitored and optimized.

Sustainable Industry 4.0 considerably increases the adjustability of production networks and the heterogeneity of manufactured items.
Balica, 2019; Chessell, 2018; Crișan-Mitra et al., 2020; Davies, 2020; Di Nardo, 2020; Grondys et al., 2020; Kliestik et al., 2018; Kovacova et al., 2019; Meilă, 2018; Popescu Ljungholm and Olah, 2020; Throne and Lăzăroiu, 2020; Trettin et al., 2019

Atwell and Lăzăroiu, 2019; Bolton et al., 2018; Dabija et al. 2019; Lăzăroiu et al., 2021; Pera, 2019; Peters et al., 2020; Popa and Dabija, 2019; Rahman et al., 2020; Scott et al., 2020; Slaby, 2019; Zhuravleva et al., 2019; Zimon et al., 2019

Dabija et al., 2018; Eskridge, 2019; Istianingsih et al., 2020; Kliestik et al., 2020; Mircică, 2019; Nelson, 2020; Nelson and Neguriță, 2020; Peters, 2020; Popescu Ljungholm, 2018; Vorontsova et al., 2020; Walker, 2020; Zhuravleva et al., 2019 
Table 2. Cont.

\begin{abstract}
Throughout cyber-manufacturing networks, production parts and smart sensors interconnect automatically, performing business process optimization and real-time big data analytics by use of cognitive decision-making algorithms across sustainable Internet of Things-based manufacturing systems.

\footnotetext{
Sustainable smart manufacturing, through data-driven Internet of Things systems, assimilates complete input of product lifecycle operations by leveraging mobile connected sensors, industrial artificial intelligence, and cognitive decision-making algorithms.
}

Balica, 2018; Borocki et al., 2019; Carter et al., 2021; Graessley et al., 2019; Grayson, 2020; He and Bai, 2020; Hyers, 2020; Meyers et al., 2019; Mirică (Dumitrescu), 2018; Popescu Ljungholm, 2018; Sheares, 2020; Tisdell et al., 2020
Deep learning-assisted smart process planning catalyzes mobility in the operations and decreases the expenses; automates the manufacturing processes; and puts into action artificial intelligence-based decision-making algorithms, sustainable organizational performance, and real-time big data analytics.

Data-driven smart manufacturing and real-time process monitoring participate in sequential assimilation, addressing efficiency optimization and furthering the consistency of the sustainable supply chain by use of operations management.

The advancement of sustainable industrial value creation, artificial intelligence-based decision-making algorithms, Internet of Things-based real-time production logistics, and deep learning-assisted smart process planning as cutting-edge technologies of Industry 4.0 have furthered the shift towards smart manufacturing systems.

The current paradigm shift of the manufacturing sector attempt to articulate cyber-physical system-based production by use of artificial intelligence-based decision-making algorithms, resulting in sustainable smart manufacturing developed on sustainable organizational performance and sustainable product lifecycle management.
Androniceanu and Tvaronavičienè, 2019; Bratu, 2019; Dabija and Băbut, 2019; Davidson, 2020; Duft and Durana, 2020; Grossman, 2018; Ionescu, 2020; Johnson, 2020; Mikhaylova et al., 2019; Popescu Ljungholm, 2018; Siekelova et al., 2020

Grant, 2021; Gray-Hawkins and Lăzăroiu, 2020; Ionescu, 2020; Kliestik et al., 2020; Miller, 2020; Pisar and Bilkova, 2019; Popescu Ljungholm, 2019; Robinson, 2020; Sekera, 2018; Sion, 2018; Wingard, 2019; Zaušková and Rezníčková, 2020

Androniceanu, 2020; Beier et al., 2020; Bell, 2020; Chovancová and Tej, 2020; Clarke, 2020; Coatney and Poliak, 2020; Davies et al., 2020; Davis et al., 2020; Di Nardo et al., 2020; Dubman, 2019; Harrower, 2019; Noack, 2019

Andronie et al., 2021; Bai et al., 2020; Bratu, 2019; Costea, 2020; Davidson, 2020; Gill-Cox, 2018; Groener, 2019; Jakimowicz and Rzeczkowski, 2019; Miller, 2020; Nica et al., 2020; Rajput and Singh, 2019; Stehel et al., 2021; Tucker, 2021

Diaz and Ocampo-Martinez, 2019; Ionescu, 2019; Ionescu, 2020; Lyons and Lăzăroiu, 2020; Nica et al., 2020; Popescu et al., 2021; Porter, 2020; Putnam et al., 2019; Sheller, 2019; Smith, 2020; Sorells, 2018; White et al., 2020; Zimon et al., 2020

Source: Processed by the authors.

\section{Cyber-Physical Production Networks in Data-Driven Sustainable Smart Manufacturing}

Smart manufacturing makes cyber-physical production networks more well-organized and sustainable $[5,25,26]$ by use of artificial intelligence-based decision-making algorithms. Big data analytics can reveal undetected knowledge and connections between lifecycle decisions and operational procedures, assisting in making better-grounded business arrangements in intricate management settings. In Internet of Things-based real-time production logistics, all manufacturing resources, artifacts, operations, and services are automated, with adjustable and variable interconnectedness and networking across the value chain. Huge volumes of data for incongruous manufacturing resources and items are generated along the entire lifecycle. Big data analytics can harness the concrete capacity and relevance of lifecycle big data to configure a smart development decision-making, as well as to assimilate and leverage adequately the cutting-edge technologies of smart manufacturing to improve competitiveness and sustainability. By deploying groundbreaking sensors, input modeling, computing, and big data analytics technologies, cyber-physical production systems can become smart and sustainable. Integrating the cutting-edge technologies of smart manufacturing with pervading servitization at all phases of product development leads to automated and sustainable production. The procedure of servitization should integrate product design, smart manufacturing, performance and maintenance, refashioning, recycling, and reprocessing phases of product lifecycle management. Implementation of sustainable smart manufacturing may assist in attaining a data- and service-driven product lifecycle management [6,14,25-27] and facilitate the omnipresent connectivity, effective consistency, and cumulative upgrade of development business processes. Sustainable smart manufacturing can assist in decreasing resources/energy waste and in cutting down 
or removing emissions from big data-driven industrial processing, consequently advancing towards the objectives of automated, sustainable, cleaner production while carrying out various temporary or lasting customer demands. Users of sustainable smart manufacturing aim to further the design and delivery of services, decreasing resource usage, deterioration, and contamination, and enhancing economic and environmental sustainability by harnessing Internet of Things-based real-time production logistics and big data analytics technologies throughout the management operations of the entire lifecycle [5,7,14,25,28,29] in order to optimize the level of automation in artificial intelligence-based decision making. Sustainable smart manufacturing focuses on servitization everywhere in the product value chain by harnessing groundbreaking information, big data analytics technologies, and large-scale upgrade of the entire product lifecycle management to assist in collating the observations obtained from big data usage. Sustainable smart manufacturing enhances the automated level of design, fabrication, servicing, and recovery by use of evaluation and distribution of lifecycle data across the entire supply chain. The goals of reducing resource inputs, energy consumption, and greenhouse gas emissions can be attained by means of sustainable and resilient product design, automated maintenance and recovery, value-based innovation, reutilization, remodeling, and recycling by use of artificial intelligence data-driven Internet of Things systems.

Data-driven sustainable smart manufacturing should be assimilated exemplarily throughout the energy system with the aim of a coherent sustainable energy transition $[8,9,14,30]$, and thus an upgrade of demand and provision with significant energy efficiency and renewable electricity sources is needed. Smart cities are redesigning the kind of production and the industry configuration. In order to maintain data-driven sustainable smart manufacturing competitiveness, the supply of a sustainable and secure energy is pivotal. The most difficult task is to forecast alterations in the energy demand and production of urban manufacturing and to adequately assimilate cyber-physical production networks into the energy system. Data-driven sustainable smart manufacturing [5,8,31-33] may lead to notably large traffic jams across mixed residential regions. Taking into account the urban economic pressure, we find that land is chiefly allocated to residential utilization in preference to industrial use. An urban location provides direct availability to customers and knowledgeable personnel who further productivity. The mixed land utilization constitutes a prospect for employing convenient renewable energies sources throughout a regional heat network. The introduction of automated assessment systems and of smart grids facilitates the articulation of load management architecture across the distribution network. Adjusting energy demand from urban manufacturing can be associated with digitalization in established urban manufacturing domains or to additive manufacturing, vertical farming, or data hubs, constituting an indispensable requirement for sustainable Internet of Things-based manufacturing systems $[8,10,14,34,35]$, cyber-physical production networks, and smart industrial value creation. Advanced prospects for the urban energy system materialize by modifying roles of urban manufacturing to a prosumer and generator of waste heat and renewable energy sources. The growing utilization of electricity from renewable energy sources throughout all sectors reinforces the decarbonization of the whole energy system. Smart technologies can supply utilities and consumers with the possibility of monitoring their systems. Data quantities will expand considerably, and more computing capacity and storage space are needed. Data-driven sustainable smart manufacturing can produce renewable energy and act as a consumer of its oversupply, using the electricity in manufacturing operations at renewable energy sources at the highest point attainable or preserving it. Designed district management and cutting-edge energy planning can provide operational support and a robust infrastructure for the organizational energy strategy.

With growing heterogeneous manufacturing demands, the production pattern has been developed into a mass-customized one $[11,23,36,37]$, but it is difficult to attain the networking between the physical realm and the digital one of the production system for the automated coordination of resources. By setting up cyber-physical links through de- 
centralized digital twin patterns, one can constitute multifarious manufacturing resources as an operational self-governing system to co-design customized products. Cutting-edge manufacturing approaches can lead to the growing amount of fashionably designed smart manufacturing assembly lines, carrying out mass-customized demands from customers. Cyber-physical systems enable the coherent forecast of the consequences of products and mechanisms in addition to performing decisions on the production system behavior without the demand for big-budget and inefficient physical duplicates. While cutting-edge sensing and streamlining infrastructure management is prevalent in smart manufacturing, assimilating the digital twin model throughout the groundbreaking production infrastructure constitutes an essential component between the physical and the cyber application layers of a cyber-physical system. Digital twin-driven manufacturing cyber-physical systems are a feasible proposal for parallel monitoring of smart plants. The digital twin is leveraged for supervising and parallel monitoring of the manufacturing system, enabling online upgrade of the cyber-physical production system [23,36-39] developed on contextual big data. A cyber-physical system is a combination of physical devices interconnecting across a virtual cyberspace by use of a data transferring network. Each physical device has its cyber component as a digital image of the concrete device, catalyzing digital twin models. The digital twin can inspect and supervise the physical entity that can transfer data to optimize and integrate its virtual model. The digital twin model represents a precise and instantaneous cyber duplicate of a physical production system that adequately mirrors all of its functionalities, assimilating big contextual data as regards work-in-process and machine, and being deployed as an infrastructure for manufacturing planning, networked upgrade, and swift remodeling. The digital twin functions as a paradigm transition, integrating production operations into manufacturing cyber-physical systems. Inconsistent with the standard simulation design, the digital twin component constitutes a confirmation tool for lifecycle integral upgrading solution and not only visual presentation of reproducing unpredictable events or reporting the outcomes. Developed on the leading-edge infrastructures by use of big data technologies [36,40-42], cyber-physical manufacturing systems gather sensory information from operational machines and work-in-processes and transmit them to the higher level networked parallel monitoring component operating throughout the digital twin computation module. Such a connected component processes the collected data, lets the physical system know the outcomes, and conveys control commands to generate indispensable alterations throughout the physical realm, or redesigns system parameters. By integrating semi-physical paralleling technology and swift networking optimization approach, one will advance an adequate iterative process, as a disconnected upgrade is inefficient in adjusting to latent disruptions and dynamic operational alterations. Developed on the digital twin performance, upgrading programs can be catalyzed in a swift fashion, and smart cyber-manufacturing assessment can indicate the necessary technological enhancement (Table 3).

Table 3. Summary of evidence concerning focus topics and descriptive results (research outcomes).

\begin{abstract}
Smart manufacturing makes cyber-physical production networks more well-organized and sustainable by use of artificial intelligence-based decision-making algorithms.
\end{abstract}

Big data analytics can harness the concrete capacity and relevance of lifecycle big data to configure smart development decision making, as well as to assimilate and leverage adequately the cutting-edge technologies of smart manufacturing to improve competitiveness and sustainability.

When groundbreaking sensors, input modeling, computing, and big data analytics technologies are deployed, cyber-physical production systems can become smart and sustainable.

Sustainable smart manufacturing can assist in decreasing resources/energy waste and in cutting down or removing emissions from big data-driven industrial processing.
Bell, 2020; Kovacova et al., 2019; Leng et al., 2019; Meyers et al., 2019; Ren et al., 2019; Vorontsova et al., 2020

Bratu, 2019; Costea, 2020; Kovacova et al., 2019; Miller, 2020; Popescu Ljungholm, 2019; Rajput and Singh, 2019; Tisdell et al., 2020; White et al., 2020

Davidson, 2020; Hughes, A. 2020; Ionescu, 2020; Jakimowicz and Rzeczkowski, 2019; Mikhaylova et al., 2019; Scott et al., 2020; Smith, 2020

Coatney and Harrower, 2019; Hyers, 2020; Miller, 2020; Mircică, 2019; Poliak, 2020; Robinson, 2020; Tötzer et al., 2019 


\section{Sustainable Organizational Performance in Cyber-Physical Smart Manufacturing Systems}

The carrying out of manufacturing cyber-physical systems necessitates accessing huge quantities of sensors, actuators, appliances, and groundbreaking production infrastructure devices with connected integrated networking processors [12-14,23,36,43-47], constituting an exemplary coherent machinery. Combination of all cyber-physical data devices into an integrated management system can assist heterogeneous digital twin models in inspecting contextual big data and accomplishing the operational upgrade (e.g., production system robustness). Throughout manufacturing processes, the digital twin assimilates instantaneous production contextual big data from work-in-process, prosumers, and machinery. Vast omnipresent data requires the adequate operational mining tools to be turned into functional input. Pattern mining, real-time sensor networks, and deep learning-assisted smart process planning deploy contextual big data $[36,48-50]$ and expose the intricate connections among work-in-process, machinery, and operational features latent or intrinsic in the manufacturing process. The cyber-physical networked production systems can interconnect by deploying conventional interfaces, inspect contextual big data to forecast failures while processing, set up manufacturing services at the Internet of Things-enabled sustainability level, and adjust to prosumer alterations socially. The manufacturing cyber-physical system possesses progressively automated linkages and networking [23,36,51-53], becoming quite resilient with the cutting-edge computing and monitoring infrastructures. Manufacturing cyber-physical systems integrate groundbreaking connectivity to gather instantaneous data produced by physical manufacturing systems and automated data management, machine learning analytics, and cyber computation. The computerized twin-driven production cognitive loop swiftly redesigns the customized requests into the monitoring parameters of the cyber-physical manufacturing system that significantly enhances operational efficiency from preparation to production. The digital twin integrates a connection to the inspection storage that includes contextual big data concerning distinct components and statistical allotments for assemblages of components. The hierarchical or centralized control system is neither adjustable nor proficient for the mass-customized pattern [23,36,51-60], in which decentralized self-managing constitutes an exemplary option. For a sequence of distinct demands and product orders, the task sub-operations are harmonized to various forms of equipment. Decentralized self-managing can perform adequately when regulating the undertakings of loosely connected networks that are extremely inconstant and self-governing. The digital twin-driven manufacturing cyber-physical system platform can upgrade dynamic execution processes. The operations of the manufacturing cyber-physical system can be virtually inspected, and input can be generated to the physical system. Performance can be refashioned and repeated until the exemplary status of a substandard operation is obtained. The task self-managing can decrease the intricacies of the inconstant networked parallel monitoring of cyberspace manufacturing flows [36,57-60] and enhance the adjustability of work-in-process for customized production demands. Digital twin determines the deployment of performance metrics to reinforce production processes and configures a standardized engineering-based strategy that facilitates incessant optimization and operational adjustability to change. The intricacies of mass customization in the inconstant manufacturing flows management are decreased, and the resilience of work-in-process for personalized production demands is enhanced.

The connection between Industry 4.0 and circular economy results in the achievement of sustainable production and consumption $[15,20-22,40,61-66]$ by taking advantage of the technological breakthroughs of smart manufacturing. The digitalization operation and the semantic networking have significant dynamic capacity and low dependence, being pivotal in enhancing resource efficiency and sustainability. Integrated Industry 4.0-circular economy reinforces sustainable operations management by constantly upgrading the production and consumption practices while supplying a prospect of personalization where end users and products interconnect and can supervise the execution of processes by using the Internet of Things sensors. Industry 4.0 is instrumental in attaining productivity and faultlessness $[14,61,67]$ by inspecting, interfacing, administering, real-time data handling, 
and self-optimizing the production process smartly through remodeling, energy use monitoring, adjustability, and forward-backward streaming of materials. Industry 4.0 may attain uniform production and consumption practices [68] and thus manufacturing efficiency can be carried out by use of technological breakthroughs. Industry 4.0 generates cutting-edge developments in sustainable operations [69], making the supply chain more fluid and coherent. Deficiencies in data collection, unprocessed materials, cleaner technologies, and interval for deployment have impacted the circular economy standards. As cutting-edge technologies developed on the mainstays of Industry 4.0 are influential $[5,61,70]$, circular economy can be implemented by harnessing Internet of Things-based real-time production logistics associated with data-driven sustainable smart manufacturing. Tracking unprocessed materials and producing instantaneous data as regards manufacturing, working parts, equipment, and post-consumption of the items are decisive in the circular economy, assisting in making knowledgeable decisions, supervising the operations, and tracing the product development, thus making sustainable smart manufacturing possible. The circular economy approach produces massive volumes of data concerning wastage, subsidiary products, and unprocessed materials, necessitating digitization throughout the supply chain to supervise and access instantaneous input.

The system architecture of big data in sustainable smart manufacturing can be harnessed to streamline the elaborate network management environment, to set out the intricate processes of lifecycle data sharing and input interoperability, and to regulate the soundness of artificial intelligence-based decision-making algorithms [5,14,17,18,25,71-76] leading to big data-driven innovation in sustainable Industry 4.0. Cutting-edge technologies can be deployed for controlling the coherence and sustainability of the smart manufacturing systems by supplying well-grounded data and significant insights. Input integration services can be offered for the shared product design operation, and thus the sustainable and groundbreaking product design and deep learning-assisted smart process planning can be attained by use of adequate management of the input collected throughout sequential product design and business process optimization in sustainable smart manufacturing through cognitive decision-making algorithms across artificial intelligence data-driven Internet of Things systems. To thoroughly harness the big data from manufacturing and energy management database to attain a significant level of sustainability, we require procedures for inspecting, assessing, and upgrading sustainability performance standards of production operations and systems. Big data analytics can adequately enable the implementation of the sustainable smart manufacturing paradigm $[25,77-80]$, by gaining value from lifecycle big data, through putting into effect servitization approaches during the entire development, and by generating innovative added-value, improving sustainability in production companies. Through big data analytics-enabled cognitive decision-making algorithms, the performance of the entire lifecycle management operations and service supplying developed on sustainable smart manufacturing can be monitored and optimized. The objectives of sustainable Industry 4.0 for deploying big data technologies, deep learning-assisted smart process planning, and advanced analytics are to decrease resource waste, to diminish environmental consequences, to further the digitization level, and to attain large-scale cognitive automation in cyber-physical manufacturing systems. On the basis of data sharing and feedback across lifecycle stages, we find that more rigorous and well-grounded product development decisions are possible, upgrading real-time process monitoring and sustainable product lifecycle management in cyber-physical system-based manufacturing $[5,14,57,81-83]$, as well as enabling the adequate deployment of optimization options. Product quality and sequential deficiency records data should be integrated and inspected to forecast the malfunction and period of effectiveness of the manufactured items, as well as to assist in configuring a projecting maintenance logistics, enhancing the reutilization rate and usage intensity of the commodities, and diminishing material and energy use. Material delivery data should be leveraged to design and indicate coextensive upgrading routes and to optimize the energy efficiency of sustainable Internet of Things-based manufacturing systems. 
Cyber-manufacturing system represents a cutting-edge configuration vision of Industry 4.0 wireless networks $[57,84]$ where physical parts are thoroughly assimilated and coherently connected with computational operations [19,85-92], constituting an on-demand, smart, and interactive production resource and capability storage with exemplary and sustainable manufacturing options. Developed on artificial intelligence-based decision-making algorithms, the cyber-manufacturing system harnesses innovative advancements in Internet of Things-based real-time production logistics, cognitive automation, and industrial big data analytics. Production resources and capabilities are embedded and networked, facilitating smart operations of manufacturing parts and systems (e.g., sensitiveness, forecast, upgrading, and layout). Cyber-manufacturing systems integrate a large volume of shared, rearrangeable, and resizable production resources and capabilities. Sustainable Industry 4.0 considerably increases the adjustability of production networks and the heterogeneity of manufactured items. In the flexible manufacturing systems, cognitive automation and adjustable monitoring tools are not designed to deploy industrial big data analytics. Cybermanufacturing systems supply exemplary options of appropriate resource/capability distribution approach, vast quantity of production devices and techniques, improved harnessing of manufacturing parts, robustness to unpredictability, and shift from production to service by use of Internet of Things sensing networks. Throughout cyber-manufacturing networks, production parts and smart sensors interconnect automatically [5,85,93-95], performing business process optimization and real-time big data analytics by use of cognitive decision-making algorithms across sustainable Internet of Things-based manufacturing systems. Sustainable smart manufacturing, through data-driven Internet of Things systems, assimilates complete input of product lifecycle operations by leveraging mobile connected sensors, industrial artificial intelligence, and cognitive decision-making algorithms. Cyber-manufacturing systems possess service-orientated production and predictive maintenance [57]: manufacturing operations are fashioned in a requirement-oriented design displayed to resource suppliers. Organizational self-monitoring regulations and parameters are established by human experts and operate progressively in conformity with data collection from physical provider layers, performing processing operations through systematizing system supervision. Cyber-physical smart manufacturing systems function in an automated, robust, and flexible manner [85,96-99], thus managing sustainability issues adequately. Self-upgrading and self-organization are advanced to find the solution to inconsistencies throughout sustainable smart manufacturing (e.g., failure incidence or source insufficiency). Performance is assessed by output, expenses, and work-in-process if manufactured items are mass-produced, or expeditiousness and cost if commodities are produced on demand (Table 4).

Table 4. Summary of evidence concerning focus topics and descriptive results (research outcomes).

\begin{abstract}
The connection between Industry 4.0 and circular economy results in the achievement of sustainable production and consumption by taking advantage of the technological breakthroughs of smart manufacturing.
\end{abstract}

Circular economy can be implemented by harnessing Internet of Things-based real-time production logistics associated with data-driven sustainable smart manufacturing.
Adams, 2020; Balica, 2018; Chovancová and Tej, 2020; Davies, 2020; Ionescu, 2019; Keane et al., 2020; Moore, 2020; Nelson and Neguriță, 2020; Pisar and Bilkova, 2019; Popescu Ljungholm, 2019; Popescu et al., 2020; Ren et al., 2019; Siekelova et al., 2020; Wingard, 2019; Zhuravleva et al., 2019

Balica, 2019; Bennett et al., 2020; Borocki et al., 2019; Bratu, 2018; Clarke, 2020; Dabija et al., 2019; Davies et al., 2020; Gray-Hawkins and Lăzăroiu, 2020; Grayson, 2020; Ionescu, 2020; Nelson, 2020; Pera, 2019; Popescu Ljungholm and Olah, 2020; Russell, 2020; Song and Moon, 2019

The system architecture of big data in sustainable smart manufacturing can be harnessed to streamline the elaborate network management environment, to set out the intricate processes of lifecycle data sharing and input interoperability, and to regulate the soundness of artificial intelligence-based decision-making algorithms leading to big data-driven innovation in sustainable Industry 4.0.
Androniceanu and Tvaronavičienè, 2019; Bekken, 2019; Chessell and Neguriță, 2020; Diaz and Ocampo-Martinez, 2019; Graessley et al., 2019; Kovacova et al., 2019; Lyons and Lăzăroiu, 2020; Meilă, 2018; Mircică, 2020; Nica et al., 2020; Peters, 2020; Sawyer, 2020; Throne and Lăzăroiu, 2020; Tötzer et al., 2019 
Table 4. Cont.

Cutting-edge technologies can be deployed for controlling the coherence and sustainability of the smart manufacturing systems by supplying well-grounded data and significant insights.
Dabija and Băbuț, 2019; Davidson, 2020; Davis et al., 2020; Duft and Durana, 2020; Grossman, 2018; Ionescu, 2020; Johnson, 2020; Leng et al., 2019; Popescu et al., 2020; Rajput and Singh, 2019; Sheares, 2020; Sion, 2018; Sorells, 2018; Williams et al., 2020

Androniceanu et al., 2020; Atwell and Lăzăroiu, 2019; Bell, 2020; Bourke et al., 2019; Bratu, 2019; Brown et al., 2020; Costea, 2020; Gill-Cox, 2018; He and Bai, 2020; Istianingsih et al., 2020; Mircică, 2019; Nica et al., 2020; Popa and Dabija, 2019; Vochozka et al., 2018
Sustainable smart manufacturing, through data-driven Internet of Things systems, assimilates complete input of product lifecycle operations by leveraging mobile connected sensors, industrial artificial intelligence, and cognitive decision-making algorithms.

\section{Industrial Big Data in Sustainable Internet of Things-Based Manufacturing Systems}

Manufacturing sectors should put into operation cyber-physical system-based smart factories $[57,61,100-107]$ to perpetuate sustainable Industry 4.0 throughout a closed-loop supply chain. Cyber-physical systems have spatio-temporal characteristics and necessitate precise and instantaneous decision-making data processing by the event handler so as to control for rigorous physical system monitoring by use of Internet of Things-based real-time production logistics. Cyber-physical system calculation operation entails discrete logical time, whereas the physical performance involves continuous physical time. Cyber-physical systems integrate various tools/parts and handle large quantities of data, making their performance more elaborate. Cyber-physical system modeling language has to adjust across the intricate setting, and thus consistent criteria and stipulations are needed. Cyber-physical production networks operate automatically and smoothly with artificial intelligence-based decision-making algorithms and Internet of Things-based realtime production logistics $[61,84,108-111]$, decreasing human participation, but various big data-driven plants necessitate distinct smart device advancement and designs, demanding investment expenses and certain time before their implementation in product decision-making information systems and sustainable Industry 4.0. Fog computation optimizes Internet of Things performance, being a spatially shared system linked to heterogeneous smart devices at the edge of Industry 4.0 wireless networks. Internet of Things-based real-time production logistics necessitates cutting-edge sensors technology (e.g., radio-frequency identification) to collect industrial big data [14,40,57,61,82,112-114] and constitute a network of heterogeneous parts/devices. Deep learning-assisted smart process planning catalyzes mobility in the operations and decreases the expenses; automates the manufacturing processes; and puts into action artificial intelligence-based decision-making algorithms, sustainable organizational performance, and real-time big data analytics. Pivotal success aspects and driving forces assist in obtaining resource efficiency, greenhouse gas emissions, energy use, and sustainable manufacturing. A shared network of smart manufacturing resources advances groundbreaking business models, assimilating production-related technologies while monitoring operations and parts instantaneously. The notable driving obstacles are equipping the circular supply chain with machines, semantic interaction between the equipment and manufactured items, collecting data across the cyber-physical system, and enhancing the production and consumption rate to optimize sustainable processes. Data-driven smart manufacturing and real-time process monitoring [61,66,115-118] participate in sequential assimilation, addressing efficiency optimization and furthering the consistency of the sustainable supply chain by use of operations management.

The smart maintenance and service constituent integrates product performance and assessment stages $[25,119-126]$ by use of cognitive decision-making algorithms. Developed on the harnessing of the smart devices for manufactured items, instantaneous performance status data of commodities can be sensed and collected while deployed by end users. For manufactured items not appropriate for integrating smart devices, external big datadriven tools are embedded throughout the installation and debugging phases. The product performance stage typically entails end-user service and manufactured item support, e.g., 
preventive, reparative, and predictive maintenance across commodity servicing phase. The instantaneous performance status data, manufactured item quality controlling data, sequential deficiency data, and end user assessment data derived from Internet of Things, smart sensors, customer feedback, and controlling system [25,57,127-129] are instrumental in end user service, manufactured item support, and mobile data-driven maintenance. Due to the structure of smart devices, product lifecycle history-related data (e.g., remaining functioning period, deterioration status, and environmental determinants) can be precisely collected at the recycle stage and can be decisive in manufactured item recovery decisionmaking and across reverse logistics planning. As a consequence of the growing deployment of cyber-physical production networks throughout Industry 4.0-based manufacturing systems $[5,25,108]$, metrics for manufactured item processes, performance, service, and maintenance can be gathered for the duration of lifecycle. By harnessing big data analytics, the huge quantities of input associated with end-user demands can be gathered and assimilated from heterogeneous sources for deriving practical insights that can be leveraged to forecast market requirements in a prompt manner, and thus the developing market magnitude, price increase, volume of competitors, and the degree of dissimilarity among manufactured items can be predicted. With respect to sustainable smart manufacturing, the disconnected lifecycle data shaping the manufactured item and service design should be assimilated and inspected to bring about relevant insights as regards product enhancements and breakthroughs.

Digitized mass production assisted by big data-driven decision-making processes is being repositioned in the direction of more coherent and sustainable systems $[5,14,57,82,130-138]$ across Internet of Things sensing networks. The advancement of sustainable industrial value creation, artificial intelligence-based decision-making algorithms, Internet of Thingsbased real-time production logistics, and deep learning-assisted smart process planning as cutting-edge technologies of Industry 4.0 have furthered the shift towards smart manufacturing systems that enable the configuration of monitoring approaches adopted instantaneously to optimize energy efficiency and adjustability of cyber-physical system-based manufacturing. Considering the decrease in fossil energy sources, ascending energy tariffs, and public regulation limitations, we find that the smart manufacturing sector is advancing in the direction of more coherent and sustainable systems. Process planning and organization are pivotal and interrelated factors in relation to energy use and adjustability of data-driven sustainable smart manufacturing. Process scheduling is performed after the operation planning phase, and generally process planning is only needed for the production of a manufactured item. The prevalently adopted strategies in sustainable Internet of Things-based manufacturing systems concentrate on the advancement of flexible operational approaches $[14,66,82,115-118,130]$ that can be adjustable concerning the energy and market demands. The current paradigm shift of the manufacturing sector attempt to articulate cyber-physical system-based production by use of artificial intelligence-based decision-making algorithms, resulting in sustainable smart manufacturing developed on sustainable organizational performance and sustainable product lifecycle management. The integration of Internet of Things smart devices, cognitive decision-making algorithms, industrial artificial intelligence, and digitized mass production furthers the design of cutting-edge monitoring strategies across Industry 4.0 wireless networks, which can be adopted instantaneously with computing interval able to find the solution to the optimization issue, shape the appropriate control operations, and carry out the coordinated undertakings to maintain the cyber-physical system in the required state. The application of Internet of Things-based real-time production logistics in the direction of a more sustainable and adjustable big data-driven manufacturing sector $[14,82,84,108-111,130]$ by decreasing resources use and custom services furthers and calls out the design of monitoring systems that has to be resilient enough to handle the intricate, wide-ranging, and networked processes of cyber-physical smart manufacturing systems. To boost the energy efficiency of the product decision-making information systems, one must enhance both 
energy use decrease and more adequate utilization of resources to attain an environmental, economic, and social sustainable development.

In sustainable Industry 4.0, a manufacturing cloud is configured and comprises both on-demand and extensively requested manufactured items $[5,85,131-136]$. The production parts in manufacturing cloud design duplicate components and the projecting characteristics considerably result in economizing the hindering period of replicating on-demand manufactured items generated by a faulty manufacturing process. The standards of monitoring strategy aim to concede the time criticality of extensively requested manufactured items that bring about reduced value, so as to ensure the time criticality of the significant value of on-demand parts. Decrease of waiting time, work-in-process expenses, and output optimization constitute the chief upsides of data-driven sustainable smart manufacturing. Such essential operational indicators display the performance optimization when shifting to Internet of Things-based real-time production logistics [85,137-142] from the bounded standard manufacturing system. The streamlined operation and work-in-process make deep learning-assisted smart process planning more sustainably manageable, while the economical attainment makes sustainable Internet of Things-based manufacturing systems competitive. Internet of Things sensing networks, industrial big data, and cyber-physical smart manufacturing systems show a significant optimization $[14,57,82,143-148]$ in the custom-designed and on-demand part production. Artificial intelligence data-driven Internet of Things systems can supply enhanced options in straightening out the bottleneck issues in material and energy use while amplifying production efficiency and estimated cost strategy. Throughout artificial intelligence data-driven Internet of Things systems, operational optimization and design are pivotal in the identification of connected tasks and monitoring of the manufacturing unit scheduling across cyber-physical system-based smart factories $[66,85,115-118]$ by use of advanced robotics, cognitive automation, and deep learning-assisted smart process planning. Sustainable Internet of Things-based manufacturing systems facilitate mass customization in terms of completion time, expenses, quality, and steadiness. By correlating the customized manufactured item with similar mass-produced commodities, by use of artificial intelligence-based decision-making algorithms [84,85,108-111], one can create tailor-made goods without undermining the performance of mass production. The automated functions can contribute to increased productivity and decrease of work-in-process throughout deep learning-assisted smart process planning and cyber-physical system-based manufacturing by sensor network implementation (Table 5).

Table 5. Summary of evidence concerning focus topics and descriptive results (research outcomes).

\begin{abstract}
Deep learning-assisted smart process planning catalyzes mobility in the operations and decreases the expenses; automates the manufacturing processes; and puts into action artificial intelligence-based decision-making algorithms, sustainable organizational performance, and real-time big data analytics.
\end{abstract}

Digitized mass production assisted by big data-driven decision-making processes is being repositioned in the direction of more coherent and sustainable systems across Internet of Things sensing networks.
The advancement of sustainable industrial value creation, artificial intelligence-based decision-making algorithms, Internet of Things-based real-time production logistics, and deep learning-assisted smart process planning as cutting-edge technologies of Industry 4.0 have furthered the shift towards smart manufacturing systems.
Androniceanu, 2020; Bai et al., 2020; Chessell, 2018; Dabija et al., 2018; Di Nardo et al., 2020; Hardingham et al., 2018; Noack, 2019; Oláh et al., 2020; Olsen, 2019; Schinckus, 2018; Sekera, 2018; Smith and Stirling, 2018; Song and Moon, 2019; Tötzer et al., 2019; Vochozka et al., 2018

Ashander et al., 2019; Beier et al., 2020; Bell, 2020; Birkel and Müller 2020; Bourke et al., 2019; Coatney, 2018; Grondys et al., 2020; Haseeb et al., 2019; Kliestik et al., 2018; Kral et al., 2019; Meilă, 2018; Nica, 2018; Popescu Ljungholm, 2018; Rajput and Singh, 2019; Sion, 2018

Bolton et al., 2018; Crișan-Mitra et al., 2020; Davis, 2020;

Ghobakhloo, 2020; Gill-Cox, 2018; Ionescu, 2020; Kliestik et al., 2020; Lyakina et al., 2019; Mirică (Dumitrescu), 2018; Popescu Ljungholm, 2018; Yadav et al., 2020; Zaušková and Rezníčková, 2020

Dabija et al., 2018; Diaz and Ocampo-Martinez, 2019; Di Nardo, 2020; Ionescu, 2019; Keane, 2020; Kliestik et al., 2020; Nica et al., 2018; Peters et al., 2020; Pisar and Bilkova, 2019; Popescu Ljungholm, 2018; Rahman et al., 2020; Ren et al., 2019; Walker, 2020
In sustainable Industry 4.0, a manufacturing cloud is configured and comprises both on-demand and extensively requested manufactured items. 


\section{Discussion}

The relevance of sustainable, smart, and sensing technologies for cyber-physical manufacturing systems is extensively in agreement with, and supplies further validation of, previous review articles, e.g., $[3,25,26,115,120,139,149]$, indicating that business process optimization throughout sustainable product lifecycle management can be carried out exemplarily by use of real-time process monitoring in Internet of Things-based manufacturing systems. Internet of Things-based real-time production logistics is pivotal in sustainable Industry 4.0 by deploying smart connected sensors that are determining in big data-driven decision-making processes. Automated production systems and industrial artificial intelligence enable the operations performed by cyber-physical system-based smart factories through big data-driven innovation and sustainable industrial value creation. The reviewed research matches the global needs by indicating how industrial big data, cognitive decision-making algorithms, and Internet of Things sensing networks are instrumental in configuring sustainable organizational performance across cyber-physical smart manufacturing systems. Internet of Things smart devices assist Industry 4.0-based manufacturing systems in articulating the big data-driven urban economy by harnessing cyber-physical production networks. Internet of Things-enabled sustainability can be attained by networking deep learning-assisted smart process planning, artificial intelligencebased decision-making algorithms, and real-time big data analytics. Sustainable Internet of Things-based manufacturing systems are competitive in digitized mass production by aiming smart industrial value creation through advanced robotics, cognitive automation, and real-time sensor networks. Sustainable smart manufacturing needs artificial intelligence data-driven Internet of Things systems to integrate in Industry 4.0 wireless networks.

The results of this systematic review develop on empirical studies [5,120-130] claiming that big data analytics, by adequately enabling the implementation of the sustainable smart manufacturing paradigm [131-138], can reveal undetected knowledge and connections between lifecycle decisions and operational procedures. Industry 4.0 generates cutting-edge developments in sustainable operations. Implementation of sustainable smart manufacturing may assist in attaining a data- and service-driven product lifecycle management. Cutting-edge manufacturing approaches can lead to the growing amount of fashionably designed smart manufacturing assembly lines. Pattern mining, real-time sensor networks, and deep learning-assisted smart process planning deploy contextual big data. Throughout cyber-manufacturing networks, production parts and smart connected sensors interconnect automatically. Cyber-physical production networks operate automatically and smoothly with artificial intelligence-based decision-making algorithms and Internet of Things-based real-time production logistics.

There has been a small but increasing number of studies [5,14,40,48-60,77-99,112-114,127-149] contending that, in Internet of Things-based real-time production logistics, all manufacturing resources, artifacts, operations, and services are automated. Sustainable smart manufacturing can assist in decreasing resources/energy waste and in cutting down or removing emissions from big data-driven industrial processing. Cutting-edge sensing and streamlining infrastructure management is prevalent in smart manufacturing. The manufacturing cyber-physical system possesses progressively automated linkages and networking. Circular economy can be implemented by harnessing Internet of Things-based real-time production logistics associated with data-driven sustainable smart manufacturing. On the basis of data sharing and feedback across lifecycle stages, we are able to generate more rigorous and well-grounded product development decisions. Sustainable smart manufacturing, through data-driven Internet of Things systems, assimilates complete input of product lifecycle operations. By harnessing big data analytics, the huge quantities of input associated with end-user demands can be gathered and assimilated from heterogeneous sources.

As underlying mechanisms between industrial artificial intelligence and cognitive decision-making algorithms are insufficiently grasped in the current literature, selected empirical studies $[5-11,14,23,26-40,75,82]$ systematically prove how big data analytics can 
harness the concrete capacity and relevance of lifecycle big data to configure a smart development decision-making. Data-driven sustainable smart manufacturing can produce renewable energy and act as a consumer of its oversupply. The digital twin is leveraged for supervising and parallel monitoring of the manufacturing system. Integrated Industry 4.0-circular economy reinforces sustainable operations management [150-160] by constantly upgrading the production and consumption practices. Cutting-edge technologies can be deployed for controlling the coherence and sustainability [161-168] of the smart manufacturing systems. The cyber-manufacturing system harnesses innovative advancements in Internet of Things-based real-time production logistics, cognitive automation, and industrial big data analytics. Cyber-physical smart manufacturing systems function in an automated, robust, and flexible manner. The integration of Internet of Things smart devices, cognitive decision-making algorithms, industrial artificial intelligence, and digitized mass production [169-180] furthers the design of cutting-edge monitoring strategies across Industry 4.0 wireless networks.

\section{Summary of the Main Results of the Research}

Cyber-physical production networks operate automatically and smoothly with artificial intelligence-based decision-making algorithms and Internet of Things-based real-time production logistics. Cyber-physical smart manufacturing systems function in an automated, robust, and flexible manner by use of Internet of Things-based real-time production logistics. Throughout cyber-manufacturing networks, production parts and smart sensors interconnect automatically, performing business process optimization and real-time big data analytics. Manufacturing cyber-physical systems integrate groundbreaking connectivity to gather instantaneous data, performing business process optimization and real-time big data analytics by use of cognitive decision-making algorithms across sustainable Internet of Things-based production systems. The manufacturing cyber-physical system possesses progressively automated linkages and networking, leading to big data-driven innovation in sustainable Industry 4.0. The integration of Internet of Things smart devices, cognitive decision-making algorithms, industrial artificial intelligence, and digitized mass production furthers the design of cutting-edge monitoring strategies across Industry 4.0 wireless networks. Industry 4.0 generates cutting-edge developments in sustainable operations and may attain uniform production and consumption practices through cognitive decision-making algorithms across artificial intelligence data-driven Internet of Things systems. Integrated Industry 4.0-circular economy reinforces sustainable operations management by constantly upgrading the production and consumption practices through big data analytics-enabled cognitive decision-making algorithms. Sustainable smart manufacturing, through data-driven Internet of Things systems, assimilates complete input of product lifecycle operations. Internet of Things-based real-time production logistics necessitates cutting-edge sensors technology to collect industrial big data, articulating cyber-physical system-based production by use of artificial intelligence-based decisionmaking algorithms.

\section{Conclusions}

Outstanding research has recently analyzed whether implementation of sustainable smart manufacturing may assist in attaining a data- and service-driven product lifecycle management. Sustainable smart manufacturing can be pivotal in decreasing resources/energy waste and in cutting down or removing emissions from big data-driven industrial processing. Data-driven sustainable smart manufacturing can produce renewable energy and act as a consumer of its oversupply. By adequately enabling the implementation of the sustainable smart manufacturing paradigm, big data analytics can reveal undetected knowledge and connections between lifecycle decisions and operational procedures. This systematic literature review displays the available published peer-reviewed evidence in relation to cutting-edge technologies that can be deployed for controlling the coherence and sustainability of the smart manufacturing systems by leveraging mobile 
connected sensors, industrial artificial intelligence, and cognitive decision-making algorithms. The objectives of sustainable Industry 4.0 for deploying big data technologies, deep learning-assisted smart process planning, and advanced analytics are to carry out manufacturing efficiency by use of technological breakthroughs. As a consequence of the growing deployment of cyber-physical production networks throughout Industry 4.0-based manufacturing systems, circular economy can be implemented by harnessing Internet of Things-based real-time production logistics associated with data-driven sustainable smart manufacturing. The findings drawn from the above analyses clarify that cutting-edge manufacturing approaches can lead to the growing amount of fashionably designed smart manufacturing assembly lines. Industry 4.0 generates cutting-edge developments in sustainable operations, as all manufacturing resources, artifacts, operations, and services are automated in Internet of Things-based real-time production logistics. The manufacturing cyber-physical system possesses progressively automated linkages and networking, harnessing innovative advancements in Internet of Things-based real-time production logistics, cognitive automation, and industrial big data analytics. Sustainable smart manufacturing has been developed on sustainable organizational performance and sustainable product lifecycle management. The advancement of sustainable industrial value creation, artificial intelligence-based decision-making algorithms, Internet of Things-based real-time production logistics, and deep learning-assisted smart process planning as cutting-edge technologies of Industry 4.0 have furthered the shift towards cyber-manufacturing networks where production parts and smart sensors interconnect automatically. Big data analytics can adequately enable the implementation of the sustainable smart manufacturing paradigm, upgrading real-time process monitoring and sustainable product lifecycle management in cyber-physical system-based manufacturing.

\section{Limitations, Implications, and Further Directions of Research}

By inspecting only sources published in outlets indexed in the Web of Science, Scopus, and ProQuest databases between 2018 and 2021, important articles on sustainable, smart, and sensing technologies for cyber-physical manufacturing systems may have been omitted. Limitations of this study include certain types of publications (original empirical research and review articles) to the detriment of others (conference proceedings articles, books, and editorial materials). The scope of our research also does not advance the analysis of intricate connections between sustainable smart manufacturing systems and Internet of Things-based real-time production logistics in terms of artificial intelligence-based decisionmaking algorithms, real-time sensor networks, and cognitive automation. There is a need for subsequent analyses to develop on deep learning-assisted smart process planning so as to configure the relevance of sustainable Industry 4.0 for cyber-physical manufacturing systems by use of industrial big data analytics, real-time sensor networks, and digitized mass production. Future research should thus investigate how cyber-physical production networks and Internet of Things-based real-time production logistics, by use of cognitive decision-making algorithms, enable the advancement of data-driven sustainable smart manufacturing. Subsequent attention should be directed to how robotic wireless sensor networks, cyber-physical system-based real-time monitoring, and deep learning-assisted smart process planning configure sustainable manufacturing Internet of Things by use of industrial big data analytics and product decision-making information systems.

Author Contributions: Conceptualization, G.L. and M.A.; methodology, R.Ș. and I.D.; validation, M.A. and G.L.; investigation, C.U. and I.D.; resources, C.U. and M.A.; data curation, R.S. and G.L.; writing-original draft preparation, M.A. and C.U.; writing-review and editing, M.A. and R.Ș.; visualization, G.L. and I.D.; supervision, C.U. and G.L.; project administration, R.Ș. and I.D. All authors have read and agreed to the published version of the manuscript.

Funding: This research received no external funding.

Institutional Review Board Statement: Not applicable.

Informed Consent Statement: Not applicable. 


\section{Data Availability Statement: Not applicable.}

Conflicts of Interest: The authors declare no conflict of interest.

\section{References}

1. Sroufe, R.; Gopalakrishna-Remani, V. Management, social sustainability, reputation, and financial performance relationships: An empirical examination of U.S. firms. Organ. Environ. 2019, 32, 331-362. [CrossRef]

2. Zimon, D.; Tyan, J.; Sroufe, R. Implementing sustainable supply chain management: Reactive, cooperative, and dynamic models. Sustainability 2019, 11, 7227. [CrossRef]

3. Shaharudin, M.S.; Fernando, Y.; Jabbour, C.J.C.; Sroufe, R.; Jasmi, M.F.A. Past, present, and future low carbon supply chain management: A content review using social network analysis. J. Clean. Prod. 2019, 218, 629-643. [CrossRef]

4. Zimon, D.; Tyan, J.; Sroufe, R. Drivers of sustainable supply chain management: Practices to alignment with UN sustainable development goals. Int. J. Qual. Res. 2020, 14, 219-236. [CrossRef]

5. Ren, S.; Zhang, Y.; Liu, Y.; Sakao, T.; Huisingh, D.; Almeida, C.M.V.B. A comprehensive review of big data analytics throughout product lifecycle to support sustainable smart manufacturing: A framework, challenges and future research directions. J. Clean. Prod. 2019, 210, 1343-1365. [CrossRef]

6. Kovacova, M.; Kliestik, T.; Valaskova, K.; Durana, P.; Juhaszova, Z. Systematic review of variables applied in bankruptcy prediction models of Visegrad group countries. Oeconom. Copernic. 2019, 10, 743-772. [CrossRef]

7. Scott, R.; Poliak, M.; Vrbka, J.; Nica, E. COVID-19 response and recovery in smart sustainable city governance and management: Data-driven Internet of Things systems and machine learning-based analytics. Geopolit. Hist. Int. Relat. 2020, 12, 16-22. [CrossRef]

8. Meyers, T.D.; Vagner, L.; Janoskova, K.; Grecu, I.; Grecu, G. Big data-driven algorithmic decision-making in selecting and managing employees: Advanced predictive analytics, workforce metrics, and digital innovations for enhancing organizational human capital. Psychosociol. Issues Hum. Resour. Manag. 2019, 7, 49-54. [CrossRef]

9. White, T.; Grecu, I.; Grecu, G. Digitized mass production, real-time process monitoring, and big data analytics systems in sustainable smart manufacturing. J. Self Gov. Manag. Econ. 2020, 8, 37-43. [CrossRef]

10. Kovacova, M.; Kliestikova, J.; Grupac, M.; Grecu, I.; Grecu, G. Automating gender roles at work: How digital disruption and artificial intelligence alter industry structures and sex-based divisions of labor. J. Res. Gend. Stud. 2019, 9, 153-159. [CrossRef]

11. Smith, A. Cognitive decision-making algorithms, real-time sensor networks, and Internet of Things smart devices in cyberphysical manufacturing systems. Econ. Manag. Financ. Mark. 2020, 15, 30-36. [CrossRef]

12. Balica, R. Big data learning analytics and algorithmic decision-making in digital education governance. Anal. Metaphys. 2018, 17, 128-133. [CrossRef]

13. Clarke, G. Sensing, smart, and sustainable technologies in big data-driven manufacturing. J. Self Gov. Manag. Econ. 2020, 8, 23-29. [CrossRef]

14. Tötzer, T.; Stollnberger, R.; Krebs, R.; Haas, M. How can urban manufacturing contribute to a more sustainable energy system in cities? Int. J. Sustain. Energy Plan. Manag. 2019, 24, 67-74. [CrossRef]

15. Sorells, B. Will robotization really cause technological unemployment? The rate and extent of potential job displacement caused by workplace automation. Psychosociol. Issues Hum. Resour. Manag. 2018, 6, 68-73. [CrossRef]

16. Porter, T. The design, regulation, and adoption of autonomous driving systems in smart sustainable urbanism. Contemp. Read. Law Soc. Justice 2020, 12, 30-36. [CrossRef]

17. Ionescu, D. Deep learning algorithms and big health care data in clinical natural language processing. Linguist. Philos. Investig. 2020, 19, 86-92. [CrossRef]

18. Nica, E.; Kliestik, T.; Sabie, O.-M.; Ioanei (Gatan), M.-L. Socio-affective technologies for psychological health: Emotional artificial intelligence in empathetic robots. Am. J. Med. Res. 2020, 7, 9-14. [CrossRef]

19. Nica, E.; Janoskova, K.; Kovacova, M. Smart connected sensors, industrial big data, and real-time process monitoring in cyber-physical system-based manufacturing. J. Self Gov. Manag. Econ. 2020, 8, 29-38. [CrossRef]

20. Chovancová, J.; Tej, J. Decoupling economic growth from greenhouse gas emissions: The case of the energy sector in V4 countries. Equilib. Q. J. Econ. Econ. Policy 2020, 15, 235-251. [CrossRef]

21. Pera, A. Towards effective workforce management: Hiring algorithms, big data-driven accountability systems, and organizational performance. Psychosociol. Issues Hum. Resour. Manag. 2019, 7, 19-24. [CrossRef]

22. Androniceanu, A.; Tvaronavičienè, M. Developing a holistic system for social assistance services based on effective and sustainable partnerships. Admin. Manag. Public 2019, 33, 103-118. [CrossRef]

23. Leng, J.; Zhang, H.; Yan, D.; Liu, Q.; Chen, X.; Zhang, D. Digital twin-driven manufacturing cyber-physical system for parallel controlling of smart workshop. J. Ambient Intell. Humaniz. Comput. 2019, 10, 1155-1166. [CrossRef]

24. Nica, E.; Miklencicova, R.; Kicova, E. Artificial intelligence-supported workplace decisions: Big data algorithmic analytics, sensory and tracking technologies, and metabolism monitors. Psychosociol. Issues Hum. Resour. Manag. 2019, 7, 31-36. [CrossRef]

25. Bell, E. Cognitive automation, business process optimization, and sustainable industrial value creation in artificial intelligence data-driven Internet of Things systems. J. Self Gov. Manag. Econ. 2020, 8, 9-15. [CrossRef]

26. Miller, K. Internet of Things-enabled smart devices in medical practice: Healthcare big data, wearable biometric sensors, and real-time patient monitoring. Am. J. Med. Res. 2020, 7, 27-33. [CrossRef] 
27. Robinson, R. Computationally networked urbanism and sensor-based big data applications in integrated smart city planning and management. Geopolit. Hist. Int. Relat. 2020, 12, 44-50. [CrossRef]

28. Tisdell, C.; Ahmad, S.; Agha, N.; Steen, J.; Verreynne, M.-L. Microfinance for wives: Fresh insights obtained from a study of poor rural women in Pakistan. J. Res. Gend. Stud. 2020, 10, 9-37. [CrossRef]

29. Hughes, A. Artificial intelligence-enabled healthcare delivery and real-time medical data analytics in monitoring, detection, and prevention of COVID-19. Am. J. Med. Res. 2020, 7, 50-56. [CrossRef]

30. Harrower, K. Algorithmic decision-making in organizations: Network data mining, measuring and monitoring work performance, and managerial control. Psychosociol. Issues Hum. Resour. Manag. 2019, 7, 7-12. [CrossRef]

31. Popescu Ljungholm, D. Regulating government and private use of unmanned aerial vehicles: Drone policymaking, law enforcement deployment, and privacy concerns. Anal. Metaphys. 2019, 18, 16-22. [CrossRef]

32. Mikhaylova, A.A.; Mikhaylov, A.S.; Savchina, O.V.; Plotnikova, A.P. Innovation landscape of the Baltic region. Admin. Manag. Public 2019, 33, 165-180. [CrossRef]

33. Hyers, D. Big data-driven decision-making processes, Industry 4.0 wireless networks, and digitized mass production in cyberphysical system-based smart factories. Econ. Manag. Financ. Mark. 2020, 15, 19-28. [CrossRef]

34. Jakimowicz, A.; Rzeczkowski, D. Do barriers to innovation impact changes in innovation activities of firms during business cycle? The effect of the Polish green island. Equilib. Q. J. Econ. Econ. Policy 2019, 14, 631-676. [CrossRef]

35. Coatney, K.; Poliak, M. Cognitive decision-making algorithms, Internet of Things smart devices, and sustainable organizational performance in Industry 4.0-based manufacturing systems. J. Self Gov. Manag. Econ. 2020, 8, 9-18. [CrossRef]

36. Costea, E.-A. Machine learning-based natural language processing algorithms and electronic health records data. Linguist. Philos. Investig. 2020, 19, 93-99. [CrossRef]

37. Davidson, R. The algorithmic governance of connected autonomous vehicles: Data-driven decision support systems and smart sustainable urban mobility behaviors. Contemp. Read. Law Soc. Justice 2020, 12, 16-24. [CrossRef]

38. Bratu, S. Can social media influencers shape corporate brand reputation? Online followers' trust, value creation, and purchase intentions. Rev. Contemp. Philos. 2019, 18, 157-163. [CrossRef]

39. Miller, E. Networked and integrated sustainable urban technologies in Internet of Things-enabled smart cities. Geopolit. Hist. Int. Relat. 2020, 12, 30-36. [CrossRef]

40. Rajput, S.; Singh, S.P. Industry 4.0-Challenges to implement circular economy. Benchmark. Int. J. 2019. Available online: https://www.emerald.com/insight/content/doi/10.1108/BIJ-12-2018-0430/full/html (accessed on 20 April 2021). [CrossRef]

41. Ionescu, L. Robotic process automation, deep learning, and natural language processing in algorithmic data-driven accounting information systems. Anal. Metaphys. 2020, 19, 59-65. [CrossRef]

42. Vorontsova, A.; Vasylieva, T.; Bilan, Y.; Ostasz, G.; Mayboroda, T. The influence of state regulation of education for achieving the sustainable development goals: Case study of Central and Eastern European countries. Admin. Manag. Public 2020, 34, 6-26. [CrossRef]

43. Keane, E.; Zvarikova, K.; Rowland, Z. Cognitive automation, big data-driven manufacturing, and sustainable industrial value creation in Internet of Things-based real-time production logistics. Econ. Manag. Financ. Mark. 2020, 15, 39-48. [CrossRef]

44. Balica, R. Automated data analysis in organizations: Sensory algorithmic devices, intrusive workplace monitoring, and employee surveillance. Psychosociol. Issues Hum. Resour. Manag. 2019, 7, 61-66. [CrossRef]

45. Meilă, A.D. Regulating the sharing economy at the local level: How the technology of online labor platforms can shape the dynamics of urban environments. Geopolit. Hist. Int. Relat. 2018, 10, 181-187. [CrossRef]

46. Dabija, D.C.; Băbuț, R. Enhancing apparel store patronage through retailers' attributes and sustainability. A generational approach. Sustainability 2019, 11, 4532. [CrossRef]

47. Mircică, N. Cyber-physical systems for cognitive Industrial Internet of Things: Sensory big data, smart mobile devices, and automated manufacturing processes. Anal. Metaphys. 2019, 18, 37-43. [CrossRef]

48. Davies, S. Interconnected sensor networks and decision-making self-driving car control algorithms in smart sustainable urbanism. Contemp. Read. Law Soc. Justice 2020, 12, 88-96. [CrossRef]

49. Russell, H. Sustainable urban governance networks: Data-driven planning technologies and smart city software systems. Geopolit. Hist. Int. Relat. 2020, 12, 9-15. [CrossRef]

50. Graessley, S.; Suler, P.; Kliestik, T.; Kicova, E. Industrial big data analytics for cognitive Internet of Things: Wireless sensor networks, smart computing algorithms, and machine learning techniques. Anal. Metaphys. 2019, 18, 23-29. [CrossRef]

51. Davis, R.; Vochozka, M.; Vrbka, J.; Neguriță, O. Industrial artificial intelligence, smart connected sensors, and big data-driven decision-making processes in Internet of Things-based real-time production logistics. Econ. Manag. Financ. Mark. 2020, 15, 9-15. [CrossRef]

52. Istianingsih, N.; Masnun, A.; Pratiwi, W. Managerial performance models through decision making and emotional intelligence in public sector. Admin. Manag. Public 2020, 35, 153-166. [CrossRef]

53. Ionescu, L. Big data, blockchain, and artificial intelligence in cloud-based accounting information systems. Anal. Metaphys. 2019, 18, 44-49. [CrossRef]

54. Chessell, D.; Neguriță, O. Smart industrial value creation, cyber-physical production networks, and real-time big data analytics in sustainable Internet of Things-based manufacturing systems. J. Self Gov. Manag. Econ. 2020, 8, 49-58. [CrossRef] 
55. Johnson, A. Medical wearables and biosensor technologies as tools of Internet of Things-based health monitoring systems. Am. J. Med. Res. 2020, 7, 7-13. [CrossRef]

56. Popa, I.D.; Dabija, D.C. Developing the Romanian organic market: A producers perspective. Sustainability 2019, 11, 467. [CrossRef]

57. Song, Z.; Moon, Y. Performance analysis of CyberManufacturing Systems. Proc. Inst. Mech. Eng. Part B J. Eng. Manuf. 2019, 233, 1362-1376. [CrossRef]

58. Adams, C. Smart sustainable urban mobility behaviors: Public attitudes and adoption intentions concerning self-driving cars. Contemp. Read. Law Soc. Justice 2020, 12, 16-22. [CrossRef]

59. Grayson, J. Big data analytics and sustainable urbanism in Internet of Things-enabled smart governance. Geopolit. Hist. Int. Relat. 2020, 12, 23-29. [CrossRef]

60. Mircică, N. Restoring public trust in digital platform operations: Machine learning algorithmic structuring of social media content. Rev. Contemp. Philos. 2020, 19, 85-91. [CrossRef]

61. Bourke, E.; Kovacova, M.; Kliestikova, J.; Rowland, Z. Smart Industrial Internet of Things devices, services, and applications: Ubiquitous sensing and sensory data, predictive analytics algorithms, and cognitive computing technologies. Anal. Metaphys. 2019, 18, 50-56. [CrossRef]

62. Siekelova, A.; Androniceanu, A.; Durana, P.; Michalikova, K.F. Earnings Management (EM), initiatives and company size: An empirical study. Acta Polytech. Hung. 2020, 17, 41-56. [CrossRef]

63. Ionescu, L. Pricing carbon pollution: Reducing emissions or GDP growth? Econ. Manag. Financ. Mark. 2020, 15, 37-43. [CrossRef]

64. Peters, E. Sustainable and smart urban transport systems: Sensing and computing technologies, intelligent vehicular networks, and data-driven automated decision-making. Contemp. Read. Law Soc. Justice 2020, 12, 43-51. [CrossRef]

65. Popescu, G.H.; Zvarikova, K.; Machova, V.; Mihai, E.-A. Industrial big data, automated production systems, and Internet of Things sensing networks in cyber-physical system-based manufacturing. J. Self Gov. Manag. Econ. 2020, 8, 30-36. [CrossRef]

66. Vochozka, M.; Kliestik, T.; Kliestikova, J.; Sion, G. Participating in a highly automated society: How artificial intelligence disrupts the job market. Econ. Manag. Financ. Mark. 2018, 13, 57-62. [CrossRef]

67. Atwell, G.J.; Lăzăroiu, G. Are autonomous vehicles only a technological step? The sustainable deployment of self-driving cars on public roads. Contemp. Read. Law Soc. Justice 2019, 11, 22-28. [CrossRef]

68. Nelson, A.; Neguriță, O. Big data-driven smart cities: Internet of Things devices and environmentally sustainable urban development. Geopolit. Hist. Int. Relat. 2020, 12, 37-43. [CrossRef]

69. Bratu, S. The ethics of algorithmic sociality, big data analytics, and data-driven research patterns. Rev. Contemp. Philos. 2018, 17, 100-106. [CrossRef]

70. Lyons, N.; Lăzăroiu, G. Addressing the COVID-19 crisis by harnessing Internet of Things sensors and machine learning algorithms in data-driven smart sustainable cities. Geopolit. Hist. Int. Relat. 2020, 12, 65-71. [CrossRef]

71. Popescu Ljungholm, D. Governing self-driving cars: Do autonomous vehicles pose a significant regulatory problem? Rev. Contemp. Philos. 2019, 18, 119-125. [CrossRef]

72. Borocki, J.; Radisic, M.; Sroka, W.; Greblikaite, J.; Androniceanu, A. Methodology for strategic posture determination of SMEs. Inz. Ekon. Eng. Econ. 2019, 30, 265-277. [CrossRef]

73. Bekken, G. The algorithmic governance of data driven-processing employment: Evidence-based management practices, artificial intelligence recruiting software, and automated hiring decisions. Psychosociol. Issues Hum. Resour. Manag. 2019, 7, 25-30. [CrossRef]

74. Duft, G.; Durana, P. Artificial intelligence-based decision-making algorithms, automated production systems, and big data-driven innovation in sustainable Industry 4.0. Econ. Manag. Financ. Mark. 2020, 15, 9-18. [CrossRef]

75. He, B.; Bai, K.-J. Digital twin-based sustainable intelligent manufacturing: A review. Adv. Manuf. 2020. [CrossRef]

76. Zhuravleva, N.A.; Cadge, K.; Poliak, M.; Podhorska, I. Data privacy and security vulnerabilities of smart and sustainable urban space monitoring systems. Contemp. Read. Law Soc. Justice 2019, 11, 56-62. [CrossRef]

77. Bennett, S.; Durana, P.; Konecny, V. Urban Internet of Things systems and interconnected sensor networks in sustainable smart city governance. Geopolit. Hist. Int. Relat. 2020, 12, 51-57. [CrossRef]

78. Kovacova, M.; Kliestik, T.; Pera, A.; Grecu, I.; Grecu, G. Big data governance of automated algorithmic decision-making processes. Rev. Contemp. Philos. 2019, 18, 126-132. [CrossRef]

79. Sheares, G. Internet of Things-enabled smart devices, biomedical big data, and real-time clinical monitoring in COVID-19 patient health prediction. Am. J. Med. Res. 2020, 7, 64-70. [CrossRef]

80. Wingard, D. Data-driven automated decision-making in assessing employee performance and productivity: Designing and implementing workforce metrics and analytics. Psychosociol. Issues Hum. Resour. Manag. 2019, 7, 13-18. [CrossRef]

81. Davies, S.; Kovacova, M.; Valaskova, K. Urban big data and Internet of Things sensing infrastructures in smart and environmentally sustainable cities. Geopolit. Hist. Int. Relat. 2020, 12, 72-78. [CrossRef]

82. Diaz, C.J.L.; Ocampo-Martinez, C. Energy efficiency in discrete-manufacturing systems: Insights, trends, and control strategies. J. Manuf. Syst. 2019, 52A, 131-145. [CrossRef]

83. Sion, G. How artificial intelligence is transforming the economy. Will cognitively enhanced machines decrease and eliminate tasks from human workers through automation? J. Self Gov. Manag. Econ. 2018, 6, 31-36. [CrossRef]

84. Gill-Cox, A. Consumer health applications, machine learning, and systems neuroscience: The use of artificial intelligence algorithms in clinical medicine and healthcare delivery. Am. J. Med. Res. 2018, 5, 46-51. [CrossRef] 
85. Pisar, P.; Bilkova, D. Controlling as a tool for SME management with an emphasis on innovations in the context of Industry 4.0. Equilib. Q. J. Econ. Econ. Policy 2019, 14, 763-785. [CrossRef]

86. Gray-Hawkins, M.; Lăzăroiu, G. Industrial artificial intelligence, sustainable product lifecycle management, and Internet of Things sensing networks in cyber-physical smart manufacturing systems. J. Self Gov. Manag. Econ. 2020, 8, 19-28. [CrossRef]

87. Grossman, T. The rise of an automated jobless society: Do cutting-edge technologies expel workers swifter than the economy can identify new jobs for them? Psychosociol. Issues Hum. Resour. Manag. 2018, 6, 62-67. [CrossRef]

88. Sawyer, J. Wearable Internet of Medical Things sensor devices, artificial intelligence-driven smart healthcare services, and personalized clinical care in COVID-19 telemedicine. Am. J. Med. Res. 2020, 7, 71-77. [CrossRef]

89. Androniceanu, A.M.; Georgescu, I.; Tvaronaviciene, M.; Androniceanu, A. Canonical correlation analysis and a new composite index on digitalization and labor force in the context of the Industrial Revolution 4.0. Sustainability 2020, 12, 6812. [CrossRef]

90. Moore, C. Medical Internet of Things-based healthcare systems: Wearable sensor-based devices, patient-generated big data, and real-time clinical monitoring. Am. J. Med. Res. 2020, 7, 41-47. [CrossRef]

91. Popescu Ljungholm, D.; Olah, M.L. Will autonomous flying car regulation really free up roads? Smart sustainable air mobility, societal acceptance, and public safety concerns. Linguist. Philos. Investig. 2020, 19, 100-106. [CrossRef]

92. Throne, O.; Lăzăroiu, G. Internet of Things-enabled sustainability, industrial big data analytics, and deep learning-assisted smart process planning in cyber-physical manufacturing systems. Econ. Manag. Financ. Mark. 2020, 15, 49-58. [CrossRef]

93. Brown, J.; Cug, J.; Kolencik, J. Internet of Things-based smart healthcare systems: Real-time patient-generated medical data from networked wearable devices. Am. J. Med. Res. 2020, 7, 21-26. [CrossRef]

94. Williams, A.; Suler, P.; Vrbka, J. Business process optimization, cognitive decision-making algorithms, and artificial intelligence data-driven Internet of Things systems in sustainable smart manufacturing. J. Self Gov. Manag. Econ. 2020, 8, 39-48. [CrossRef]

95. Nelson, A. Smart transportation systems: Sustainable mobilities, autonomous vehicle decision-making algorithms, and networked driverless technologies. Contemp. Read. Law Soc. Justice 2020, 12, 25-33. [CrossRef]

96. Davidson, R. Cyber-physical production networks, artificial intelligence-based decision-making algorithms, and big data-driven innovation in Industry 4.0-based manufacturing systems. Econ. Manag. Financ. Mark. 2020, 15, 16-22. [CrossRef]

97. Bratu, S. Nutritional genomics in personalized medicine: Data-driven customized treatments and lifestyle-based disease management and prevention. Linguist. Philos. Investig. 2019, 18, 140-146. [CrossRef]

98. Popescu, G.H.; Valaskova, K.; Majerova, J. Real-time sensor networks, advanced robotics, and product decision-making information systems in data-driven sustainable smart manufacturing. Econ. Manag. Financ. Mark. 2020, 15, 29-38. [CrossRef]

99. Dabija, D.C.; Bejan, B.; Dinu, V. How sustainability oriented is generation Z in retail? A literature review. Transform. Bus. Econ. 2019, 18, 140-155.

100. Ionescu, L. Digital data aggregation, analysis, and infrastructures in FinTech operations. Rev. Contemp. Philos. 2020, 19, 92-98. [CrossRef]

101. Keane, J. Can self-driving cars lead to sustainability? Autonomous smart sensors, perception and planning algorithms, and data processing efficiency. Contemp. Read. Law Soc. Justice 2020, 12, 9-15. [CrossRef]

102. Olsen, M. Using data analytics in the management of employees: Digital means of tracking, monitoring, and surveilling worker activities. Psychosociol. Issues Hum. Resour. Manag. 2019, 7, 43-48. [CrossRef]

103. Kral, P.; Janoskova, K.; Podhorska, I.; Pera, A.; Neguriță, O. The automatability of male and female jobs: Technological unemployment, skill shift, and precarious work. J. Res. Gend. Stud. 2019, 9, 146-152. [CrossRef]

104. Davis, R. Integrating digital technologies and data-driven telemedicine into smart healthcare during the COVID-19 pandemic. Am. J. Med. Res. 2020, 7, 22-28. [CrossRef]

105. Peters, E.; Kliestik, T.; Musa, H.; Durana, P. Product decision-making information systems, real-time big data analytics, and deep learning-enabled smart process planning in sustainable Industry 4.0. J. Self Gov. Manag. Econ. 2020, 8, 16-22. [CrossRef]

106. Noack, B. Big data analytics in human resource management: Automated decision-making processes, predictive hiring algorithms, and cutting-edge workplace surveillance technologies. Psychosociol. Issues Hum. Resour. Manag. 2019, 7, 37-42. [CrossRef]

107. Grondys, K.; Androniceanu, A.; Dacko-Pikiewicz, Z. Energy management in the operation of enterprises in the light of the applicable provisions of the Energy Efficiency Directive (2012/27/EU). Energies 2020, 13, 4338. [CrossRef]

108. Ionescu, D. Semantically enriched Internet of Things sensor data in smart networked environments. Anal. Metaphys. 2019, 18, 30-36. [CrossRef]

109. Smith, A.; Stirling, A. Innovation, sustainability and democracy: An analysis of grassroots contributions. J. Self Gov. Manag. Econ. 2018, 6, 64-97. [CrossRef]

110. Kliestik, T.; Misankova, M.; Valaskova, K.; Svabova, L. Bankruptcy prevention: New effort to reflect on legal and social changes. Sci. Eng. Ethics 2018, 24, 791-803. [CrossRef] [PubMed]

111. Jandacka, J.; Mičieta, J.; Holubcik, M.; Nosek, R. Experimental determination of bed temperatures during wood pellet combustion. Energy Fuels 2017, 31, 2919-2926. [CrossRef]

112. Lenhard, R.; Malcho, M.; Jandacka, J. Modelling of heat transfer in the evaporator and condenser of the working fluid in the heat pipe. Heat Transf. Eng. 2019, 40, 215-226. [CrossRef]

113. Hadzima, B.; Janecek, M.; Estrin, Y.; Kim, H.S. Microstructure and corrosion properties of ultrafine-grained interstitial free steel. Mater. Sci. Eng. A 2007, 462, 243-247. [CrossRef]

114. Schinckus, C. From DNA to economics: Analogy in econobiology. Rev. Contemp. Philos. 2018, 17, 31-42. [CrossRef] 
115. Ashander, L.; Kliestikova, J.; Durana, P.; Vrbska, J. The decision-making logic of big data algorithmic analytics. Contemp. Read. Law Soc. Justice 2019, 11, 57-62. [CrossRef]

116. Popescu Ljungholm, D. Reality-construction processes in information societies: Algorithmic regulation, automated decisionmaking, and networked governance. Rev. Contemp. Philos. 2018, 17, 107-113. [CrossRef]

117. Popescu Ljungholm, D. Regulation of automated individual decision-making and artificially intelligent algorithmic systems: Is the GDPR a powerful enough mechanism to protect data subjects? Anal. Metaphys. 2018, 17, 116-121. [CrossRef]

118. Androniceanu, A. Major structural changes in the EU policies due to the problems and risks caused by COVID-19. Admin. Manag. Public 2020, 34, 137-149. [CrossRef]

119. Sion, G. Smart educational ecosystems: Cognitive engagement and machine intelligence algorithms in technology-supported learning environments. Anal. Metaphys. 2018, 17, 140-145. [CrossRef]

120. Bolton, C.; Machová, V.; Kovacova, M.; Valaskova, K. The power of human-machine collaboration: Artificial intelligence, business automation, and the smart economy. Econ. Manag. Financ. Mark. 2018, 13, 51-56. [CrossRef]

121. Kliestik, T.; Valaskova, K.; Nica, E.; Kovacova, M.; Lăzăroiu, G. Advanced methods of earnings management: Monotonic trends and change-points under spotlight in the Visegrad countries. Oeconom. Copernic. 2020, 11, 371-400. [CrossRef]

122. Sekera, J. Missing from the mainstream: The biophysical basis of production and the public economy. Econ. Manag. Financ. Mark. 2018, 13, 56-73. [CrossRef]

123. Meilă, A.D. Sustainable urban mobility in the sharing economy: Digital platforms, collaborative governance, and innovative transportation. Contemp. Read. Law Soc. Justice 2018, 10, 130-136. [CrossRef]

124. Popescu Ljungholm, D. Sharing economy, regulatory arbitrage, and urban governance: How city space shapes economic growth and innovation. Geopolit. Hist. Int. Relat. 2018, 10, 174-180. [CrossRef]

125. Kliestik, T.; Nica, E.; Musa, H.; Poliak, M.; Mihai, E.-A. Networked, smart, and responsive devices in Industry 4.0 manufacturing systems. Econ. Manag. Financ. Mark. 2020, 15, 23-29. [CrossRef]

126. Hardingham, E.; Vrbka, J.; Kliestik, T.; Kliestikova, J. Will cognitive technology-driven automation lead to economic growth? J. Self Gov. Manag. Econ. 2018, 6, 13-18. [CrossRef]

127. Nica, E.; Manole, C.; Stan, C.I. A laborless society? How highly automated environments and breakthroughs in artificial intelligence bring about innovative kinds of skills and employment disruptions, altering the nature of business process and affecting the path of economic growth. J. Self Gov. Manag. Econ. 2018, 6, 25-30. [CrossRef]

128. Haseeb, M.; Hussain, H.I.; Kot, S.; Androniceanu, A.; Jermsittiparsert, K. Role of social and technological challenges in achieving a sustainable competitive advantage and sustainable business performance. Sustainability 2019, 11, 3811. [CrossRef]

129. Mirică (Dumitrescu), C.-O. Online contingent labor in a precarious capitalism: Platform business models, nonstandard forms of employment, and digitally driven sharing-economy services. J. Self Gov. Manag. Econ. 2018, 6, 129-135. [CrossRef]

130. Dabija, D.C.; Bejan, B.; Grant, D. The impact of consumer green behaviour on green loyalty among retail formats: A Romanian case study. Morav. Geogr. Rep. 2018, 26, 173-185. [CrossRef]

131. Nica, E. Will robots take the jobs of human workers? Disruptive technologies that may bring about jobless growth and enduring mass unemployment. Psychosociol. Issues Hum. Resour. Manag. 2018, 6, 56-61. [CrossRef]

132. Crișan-Mitra, C.; Stanca, L.; Dabija, D.C. Corporate social performance: An assessment model on an emerging market. Sustainability 2020, 12, 4077. [CrossRef]

133. Walker, A. Internet of Things-enabled smart sustainable cities: Big data-based urban governance, wireless sensor networks, and automated algorithmic decision-making processes. Geopolit. Hist. Int. Relat. 2020, 12, 58-64. [CrossRef]

134. Chessell, D. The jobless economy in a post-work society: How automation will transform the labor market. Psychosociol. Issues Hum. Resour. Manag. 2018, 6, 74-79. [CrossRef]

135. Coatney, K. Big data analytics capabilities, the business value of information technology, and healthcare organizations: The need for consensus in evidence-based medical practices. Am. J. Med. Res. 2018, 5, 28-33. [CrossRef]

136. Zaušková, A.; Rezníčková, M. SoLoMo marketing as a global tool for enhancing awareness of eco-innovations in Slovak business environment. Equilib. Q. J. Econ. Econ. Policy 2020, 15, 133-150. [CrossRef]

137. Dabija, D.C.; Bejan, B.; Tipi, N. Generation X versus Millennials communication behavior on social media when purchasing food versus tourist services. Econ. Manag. 2018, 21, 191-205. [CrossRef]

138. Bai, C.; Dallasega, P.; Orzes, G.; Sarkis, J. Industry 4.0 technologies assessment: A sustainability perspective. Int. J. Prod. Econ. 2020, 229, 107776. [CrossRef]

139. Birkel, H.S.; Müller, J.M. Potentials of Industry 4.0 for Supply Chain Management within the Triple Bottom Line of Sustainability-A Systematic Literature Review. J. Clean. Prod. 2020, 289, 125612. [CrossRef]

140. Yadav, G.; Kumar, A.; Luthra, S.; Garza-Reyes, J.A.; Kumar, V.; Batista, L. A framework to achieve sustainability in manufacturing organisations of developing economies using industry 4.0 technologies' enablers. Comput. Ind. 2020, 122, 103280. [CrossRef]

141. Oláh, J.; Aburumman, N.; Popp, J.; Khan, M.A.; Haddad, H.; Kitukutha, N. Impact of Industry 4.0 on environmental sustainability. Sustainability 2020, 12, 4674. [CrossRef]

142. Rahman, S.M.; Perry, N.; Müller, J.M.; Kim, J.; Laratte, B. End-of-Life in industry 4.0: Ignored as before? Resour. Conserv. Recycl. 2020, 154, 104539. [CrossRef]

143. Beier, G.; Ullrich, A.; Niehoff, S.; Reißig, M.; Habich, M. Industry 4.0: How it is defined from a sociotechnical perspective and how much sustainability it includes-A literature review. J. Clean. Prod. 2020, 259, 120856. [CrossRef] 
144. Ghobakhloo, M. Industry 4.0, digitization, and opportunities for sustainability. J. Clean. Prod. 2020, 252, 119869. [CrossRef]

145. Di Nardo, M. Developing a conceptual framework model of Industry 4.0 for industrial management. Ind. Eng. Manag. Syst. 2020, 19, 551-560. [CrossRef]

146. Di Nardo, M.; Clericuzio, M.; Murino, T.; Sepe, C. An Economic Order Quantity Stochastic Dynamic Optimization Model in a Logistic 4.0 Environment. Sustainability 2020, 12, 4075. [CrossRef]

147. Di Nardo, M.; Gallo, M.; Murino, T.; Santillo, L. System Dynamics Simulation for Fire and Explosion Risk Analysis in Home Environment. Int. Rev. Model. Simul. IREMOS 2017, 10, 43-54. [CrossRef]

148. Lyakina, M.; Heaphy, W.; Konecny, V.; Kliestik, T. Algorithmic Governance and Technological Guidance of Connected and Autonomous Vehicle Use: Regulatory Policies, Traffic Liability Rules, and Ethical Dilemmas. Contemp. Read. Law Soc. Justice 2019, 11, 15-21. [CrossRef]

149. Grant, E. Big Data-driven Innovation, Deep Learning-assisted Smart Process Planning, and Product Decision-Making Information Systems in Sustainable Industry 4.0. Econ. Manag. Financ. Mark. 2021, 16, 9-19. [CrossRef]

150. Carter, D.; Kolencik, J.; Cug, J. Smart Internet of Things-enabled Mobile-based Health Monitoring Systems and Medical Big Data in COVID-19 Telemedicine. Am. J. Med. Res. 2021, 8, 20-29. [CrossRef]

151. Sheller, T. Datafied Urban Governance: Real-Time Data Sustainability, Smart Digital Technologies, and the Citizen-driven Internet of Things. Geopolit. Hist. Int. Relat. 2019, 11, 13-19. [CrossRef]

152. Slaby, C. Decision-Making Self-Driving Car Control Algorithms: Intelligent Transportation Systems, Sensing and Computing Technologies, and Connected Autonomous Vehicles. Contemp. Read. Law Soc. Justice 2019, 11, 29-35. [CrossRef]

153. Tucker, G. Sustainable Product Lifecycle Management, Industrial Big Data, and Internet of Things Sensing Networks in CyberPhysical System-based Smart Factories. J. Self Gov. Manag. Econ. 2021, 9, 9-19. [CrossRef]

154. Durana, P.; Perkins, N.; Valaskova, K. Artificial Intelligence Data-driven Internet of Things Systems, Real-Time Advanced Analytics, and Cyber-Physical Production Networks in Sustainable Smart Manufacturing. Econ. Manag. Financ. Mark. 2021, 16, 20-30. [CrossRef]

155. Dubman, R. The Digital Governance of Data-driven Smart Cities: Sustainable Urban Development, Big Data Management, and the Cognitive Internet of Things. Geopolit. Hist. Int. Relat. 2019, 11, 34-40. [CrossRef]

156. Groener, M. Automated Robotic and Network Connectivity Systems for Self-Driving Vehicle Technology. Contemp. Read. Law Soc. Justice 2019, 11, 36-42. [CrossRef]

157. Lăzăroiu, G.; Kliestik, T.; Novak, A. Internet of Things Smart Devices, Industrial Artificial Intelligence, and Real-Time Sensor Networks in Sustainable Cyber-Physical Production Systems. J. Self Gov. Manag. Econ. 2021, 9, 20-30. [CrossRef]

158. Durst, M. Internet of Things-enabled Smart Governance and the Sustainable Development of Innovative Data-driven Urban Ecosystems. Geopolit. Hist. Int. Relat. 2019, 11, 20-26. [CrossRef]

159. Mitchell, K. Internet of Things-enabled Smart Devices, Healthcare Body Sensor Networks, and Online Patient Engagement in COVID-19 Prevention, Screening, and Treatment. Am. J. Med. Res. 2021, 8, 30-39. [CrossRef]

160. Watkins, D. Real-Time Big Data Analytics, Smart Industrial Value Creation, and Robotic Wireless Sensor Networks in Internet of Things-based Decision Support Systems. Econ. Manag. Financ. Mark. 2021, 16, 31-41. [CrossRef]

161. Cunningham, E. Artificial Intelligence-based Decision-Making Algorithms, Sustainable Organizational Performance, and Automated Production Systems in Big Data-Driven Smart Urban Economy. J. Self Gov. Manag. Econ. 2021, 9, 31-41. [CrossRef]

162. Rogers, R. Internet of Things-based Smart Healthcare Systems, Wireless Connected Devices, and Body Sensor Networks in COVID-19 Remote Patient Monitoring. Am. J. Med. Res. 2021, 8, 71-80. [CrossRef]

163. Gutschow, E. Big Data-driven Smart Cities: Computationally Networked Urbanism, Real-Time Decision-Making, and the Cognitive Internet of Things. Geopolit. Hist. Int. Relat. 2019, 11, 48-54. [CrossRef]

164. Mircică, N. The Design, Implementation, and Operation of Self-Driving Cars: Ethical, Security, Safety, and Privacy Issues. Contemp. Read. Law Soc. Justice 2019, 11, 43-48. [CrossRef]

165. Andronie, M.; Lăzăroiu, G.; Iatagan, M.; Hurloiu, I.; Dijmărescu, I. Sustainable Cyber-Physical Production Systems in Big Data-Driven Smart Urban Economy: A Systematic Literature Review. Sustainability 2021, 13, 751. [CrossRef]

166. Stehel, V.; Bradley, C.; Suler, P.; Bilan, S. Cyber-Physical System-based Real-Time Monitoring, Industrial Big Data Analytics, and Smart Factory Performance in Sustainable Manufacturing Internet of Things. Econ. Manag. Financ. Mark. 2021, $16,42-51$. [CrossRef]

167. Riegler, C. The Moral Decision-Making Capacity of Self-Driving Cars: Socially Responsible Technological Development, Algorithm-driven Sensing Devices, and Autonomous Vehicle Ethics. Contemp. Read. Law Soc. Justice 2019, 11, 15-20. [CrossRef]

168. Morgan, V.; Birtus, M.; Zauskova, A. Medical Internet of Things-based Healthcare Systems, Wearable Biometric Sensors, and Personalized Clinical Care in Remotely Monitoring and Caring for Confirmed or Suspected COVID-19 Patients. Am. J. Med. Res. 2021, 8, 81-90. [CrossRef]

169. Zhuravleva, N.A.; Nica, E.; Durana, P. Sustainable Smart Cities: Networked Digital Technologies, Cognitive Big Data Analytics, and Information Technology-driven Economy. Geopolit. Hist. Int. Relat. 2019, 11, 41-47. [CrossRef]

170. Riley, C.; Vrbka, J.; Rowland, Z. Internet of Things-enabled Sustainability, Big Data-driven Decision-Making Processes, and Digitized Mass Production in Industry 4.0-based Manufacturing Systems. J. Self Gov. Manag. Econ. 2021, 9, 42-52. [CrossRef]

171. McGinnis, C. Technologies of Transit and Mobile Values Implemented in Artificial Intelligence Algorithms that Control Fully Autonomous Driving Vehicles. Contemp. Read. Law Soc. Justice 2019, 11, 27-32. [CrossRef] 
172. Nica, E.; Stan, C.I.; Luțan (Petre), A.G.; Oașa (Geambazi), R.-Ș. Internet of Things-based Real-Time Production Logistics, Sustainable Industrial Value Creation, and Artificial Intelligence-driven Big Data Analytics in Cyber-Physical Smart Manufacturing Systems. Econ. Manag. Financ. Mark. 2021, 16, 52-62. [CrossRef]

173. Trettin, C.; Lăzăroiu, G.; Grecu, I.; Grecu, G. The Social Sustainability of Citizen-centered Urban Governance Networks: Sensorbased Big Data Applications and Real-Time Decision-Making. Geopolit. Hist. Int. Relat. 2019, 11, 27-33. [CrossRef]

174. Eskridge, M. Privacy and Security Data Governance: Surveillance Mechanisms and Resilience Risks of Smart City Technologies. Contemp. Read. Law Soc. Justice 2019, 11, 63-69. [CrossRef]

175. Popescu, C.K.; Oașa Geambazi, R.-Ș.; Geambazi, P.; Alexandru, B. Real-Time Process Monitoring, Industry 4.0 Wireless Networks, and Cognitive Automation in Cyber-Physical System-based Manufacturing. J. Self Gov. Manag. Econ. 2021, 9, 53-63. [CrossRef]

176. Gutberlet, T. Data-driven Smart Sustainable Cities: Highly Networked Urban Environments and Automated Algorithmic Decision-Making Processes. Geopolit. Hist. Int. Relat. 2019, 11, 55-61. [CrossRef]

177. Rowthorn, M. How Should Autonomous Vehicles Make Moral Decisions? Machine Ethics, Artificial Driving Intelligence, and Crash Algorithms. Contemp. Read. Law Soc. Justice 2019, 11, 9-14. [CrossRef]

178. Bailey, L. Wearable Internet of Things Healthcare Systems, Virtual Care, and Real-Time Clinical Monitoring in Assessing and Treating Patients with COVID-19 Symptoms. Am. J. Med. Res. 2021, 8, 91-100. [CrossRef]

179. Lyakina, M.; Sheehy, M.; Podhorska, I. Networked and Integrated Urban Technologies in Internet of Things-enabled Smart Sustainable Cities. Geopolit. Hist. Int. Relat. 2019, 11, 62-68. [CrossRef]

180. Putnam, D.; Kovacova, M.; Valaskova, K.; Stehel, V. The Algorithmic Governance of Smart Mobility: Regulatory Mechanisms for Driverless Vehicle Technologies and Networked Automated Transport Systems. Contemp. Read. Law Soc. Justice 2019, 11, 21-26. [CrossRef] 